\title{
Design, Synthesis and Anticancer Activity of New Polycyclic: Imidazole, Thiazine, Oxathiine, Pyrrolo-Quinoxaline and Thienotriazolopyrimidine Derivatives
}

\author{
Ameen Ali Abu-Hashem ${ }^{1,2, *(D)}$, Sami A. Al-Hussain ${ }^{3}$ and Magdi E. A. Zaki ${ }^{1,3}$ \\ 1 Heterocyclic Unit, National Research Centre, Photochemistry Department, Dokki, Giza 12622, Egypt; \\ mezaki@imamu.edu.sa or meazaki@gmail.com \\ 2 Chemistry Department, Faculty of Science, Jazan University, Jazan 45142, Saudi Arabia \\ 3 Department of Chemistry, Faculty of Science, Imam Mohammad Ibn Saud Islamic University (IMSIU), \\ Riyadh 13318, Saudi Arabia; sahussain@imamu.edu.sa \\ * Correspondence: aminaliabuhashem@yahoo.com or aaabuhashem@jazanu.edu.sa; Tel.: +20-012-2521-1700 or \\ +966-591-363-915; Fax: +20-2-3337-0931
}

\section{check for}

updates

Citation: Abu-Hashem, A.A.; Al-Hussain, S.A.; Zaki, M.E.A. Design, Synthesis and Anticancer Activity of New Polycyclic: Imidazole, Thiazine, Oxathiine,

Pyrrolo-Quinoxaline and Thienotriazolopyrimidine Derivatives. Molecules 2021, 26, 2031. https://doi.org/10.3390/ molecules26072031

Academic Editor: Brullo Chiara

Received: 6 March 2021

Accepted: 23 March 2021

Published: 2 April 2021

Publisher's Note: MDPI stays neutral with regard to jurisdictional claims in published maps and institutional affiliations.

Copyright: (c) 2021 by the authors. Licensee MDPI, Basel, Switzerland. This article is an open access article distributed under the terms and conditions of the Creative Commons Attribution (CC BY) license (https:/ / creativecommons.org/licenses/by/ $4.0 /)$.

\begin{abstract}
In this article, we showed the synthesis of new polycyclic aromatic compounds, such as thienotriazolopyrimidinones, $N$-(thienotriazolopyrimidine) acetamide, 2-mercapto-thienotriazolopyrimidinones, 2-((thieno-triazolopyrimidine) methyl) thio) thieno-triazolopyrimidines, thienopyrimidotriazolo-thiazines, pyrrolo-triazolo-thienopyrimidines, thienopyrimido-triazolopyrroloquinoxalines, thienopyrimido-triazolo-pyrrolo-oxathiino-quinoxalinones, 1,4-oxathiino-pyrrolo- triazolothienopyrimidinones, imidazopyrrolotriazolothienopyrimidines and 1,2,4-triazoloimidazopyrrolotriazolothienopyrimidindiones, based on the starting material 2,3-diamino-6-benzoyl-5methylthieno[2,3-d]pyrimidin-4(3H)-one (3). The chemical structures were confirmed using many spectroscopic ways (IR, ${ }^{1} \mathrm{H},{ }^{13} \mathrm{C},-\mathrm{NMR}$ and MS) and elemental analyses. A series of thiazine, imidazole, pyrrole, thienotriazolopyrimidine derivatives were synthesized and evaluated for their antiproliferative activity against four human cancer cell lines, i.e., CNE2 (nasopharyngeal), KB (oral), MCF-7 (breast) and MGC-803 (gastric) carcinoma cells. The compounds 20, 19, 17, 16 and 11 showed significant cytotoxicity against types of human cancer cell lines.
\end{abstract}

Keywords: thienopyrimidinone; thienotriazolopyrimidinone; 1,2,4-triazole; thiazine; pyrrole; oxathiinoquinoxaline; imidazole; imidazopyrrolotriazole; anticancer activity

\section{Introduction}

Cancer is one of the most recent serious diseases that afflict humans and ultimately leads to their death. From here, researchers began to develop and discover much effective anticancer therapeutics, such as treatment of cancer using chemotherapy [1] and heterocyclic compounds, such as thienopyrimidine, triazolopyrimidine, quinoxaline and imidazole derivatives containing anticancer drugs [2], as follows: Azathioprine, Pimonidazole, Dacarbazine, Misonidazole, Fadrozole, Tipifarnib, Bendamustine, Indimitecan and Nilotinib. Therefore, the chemical studies of each of thiophene, pyrimidine, triazole, thiazine, pyrrole, quinoxaline and imidazole nucleus play a significant role in the synthesis of a diversity of fused heterocyclic compounds having a wide range of biological and pharmacological activities. Accordingly, previous scientific studies confirmed that thienopyrimidine derivatives have various biological and pharmacological activities, such as antibiotics [3], antimicrobial [4,5], anticonvulsants [6], antiviral [7], antioxidant and antitumor agents [8], anticancer [9] and mitotic arrest of breast cancer [10], anti-inflammatory and analgesic activities [11,12], antiglaucoma agents [13], platelet aggregation inhibitors [14], anti-hyperlipidemia [15], antidepressant, anti-inflammatory and antimicrobial activities [16]. In addition, the thiazolopyrimidine, 1,2,4-triazolopy- rimidine and thienotriazolopyrimidinone derivatives possess such biological activities as 
anti-inflammatory and analgesic activity [17,18], antimicrobial [19] and anticancer activity through a potential of the enzyme (PARP-1) inhibition [20]. Lately, in connection to continuing work in the synthesis and biological evaluation of new polycyclic fused thienopyrimidine, purine and 1,2,4-triazole systems, purine derivatives are of great importance and wide applications in many biological activities, such as antitumor [21] and the potential xanthine oxidase (XO)-inhibitory activities, as well as many biological activities when fused with 1,2,4-triazole ring, shown in Figure 1, as the following: $7 \beta$-D-ribofuranosyl1,2,4-triazolopurines (A) [22], 1,2,4-triazolopurines (B) [23], thienotriazolopyrimidinones (C) and 2-sub-thienotriazolopyrimidinones (D) as a new class of the $\mathrm{XO}$ inhibitors [24]. Additionally, Azathioprine (E) is an anticancer drug that possesses considerable potential, because of its ability to interfere with DNA prepared and then stop growth and division cells and it is used for the treatment of metastatic malignant melanoma and cell carcinoma of the pancreas [25].<smiles>[R]c1nnc2c3ncn([C@@H]4O[C@H](CO)[C@@H](O)[C@H]4O)c3[nH]c(=O)n12</smiles>

(A)<smiles>[R]c1nnc2c3[nH]cnc3[nH]c(=O)n12</smiles>

(B)<smiles>[R]c1nnc2c3sccc3[nH]c(=O)n12</smiles>

(C)<smiles>[R]c1nc2c3ccsc3[nH]c(=O)n2n1</smiles>

(D)<smiles>Cn1cnc([N+](=O)[O-])c1SC1=NC=NC2N=CNC12</smiles>

(E)

Figure 1. Chemical structures of formerly synthesized drugs: triazolopurines and thienotriazolo- pyrimidines analogues.

The nitrogen atoms containing heterocycles, especially, display a different range of biological activities, due to their similarities with numerous synthetic and natural molecules with recognized biological activities [26]. The benzimidazole and imidazole rings have been generally used as the substantial basic structure for the development of therapeutic molecules of biological and pharmaceutical activities. An example of five-membered heterocycles is imidazole, which is spread between the significant biological building blocks. Thus, many drugs contain imidazole, such as the following: Sertaconazole is used as an antifungal agent [27]. Omeprazole is antiulcer and controls the acid secretion in the stomach and it is considered clinically superior to $\mathrm{H}_{2}$-receptor antagonists [28,29]. Mizolastine is an antihistaminic and potent antagonist at $\mathrm{H}_{1}$ receptor sites for the treatment of allergic rhinoconjunctivitis and urticarial [30]. Candesartan is used as a receptor antagonist, because it contains a bulky lipophilic group, carboxylic acid, the biphenyl group that is more efficient than the tetrazole analogue [31]. Azanidazole is an antiparasitic drug and used as an antibacterial and antiprotozoal drug [32]. Maribavir is an antiviral drug, which is used in the treatment and prevention of human cytomegalovirus (HCMV) disease in hematopoietic stem cell/bone marrow transplant patients [33], as shown in Figure 2.

This article is a supplement of our former work about the preparation of heterocyclic compounds resulting from pyrimidine and thienopyrimidine derivatives, which possess biological activities $[4,5,8,11,12,19-21,34-48]$. In this manuscript, these compounds, thienotriazolopyrimidinone, thienopyrimidotriazolopyrrolooxathiinoquinoxalines and 1,2,4-triazoloimidazopyrrolotriazolothienopyrimidinedione derivatives were synthesized from 2,3-diamino-6-benzoyl-5-methylthieno[2,3-d]pyrimidinone and evaluated as having antiproliferative activities against types of human carcinoma cancer cell lines. 
<smiles>Clc1ccc(C(Cn2ccnc2)OCc2csc3c(Cl)cccc23)c(Cl)c1</smiles>

Sertaconazole<smiles>CCOc1nc2cccc(C(=O)O)c2n1Cc1ccc(-c2ccccc2-c2nn[nH]n2)cc1</smiles>

Candesartan<smiles>COc1ccc2[nH]c(S(=O)Cc3ncc(C)c(OC)c3C)nc2c1</smiles>

Omeprazole<smiles>Cn1c([N+](=O)[O-])cnc1/C=C\c1ccnc(N)n1</smiles>

Azanidazole<smiles>CC(C)Nc1nc2cc(Cl)c(Cl)cc2n1[C@@H]1O[C@H](CO)[C@@H](O)[C@H]1O</smiles>

Maribavir

Figure 2. Chemical structures of formerly synthesized drugs: benzimidazoles and imidazoles.

\section{Results and Discussion}

\subsection{Synthesis}

The 2-(4-aminophenyl)-6-benzoyl-7-methylthieno[2,3-d][1,2,4]triazolo[1,5-a] pyrimidin$8(3 H)$-one (4) was synthesized via the oxidative cyclization of 2,3-diamino- 6-benzoyl-5methylthieno[2,3-d]pyrimidin-4(3H)-one (3) $[4,18]$ and 4-aminobenzoic acid in polyphosphoric acid at $250-280{ }^{\circ} \mathrm{C}$ for $18-20 \mathrm{~h}$. The IR spectra of compound 4 showed the presence of a broad bands absorption at 3405 and $3355 \mathrm{~cm}^{-1}$ of one $\mathrm{NH}_{2}$ and one $\mathrm{NH}$ group and two bands absorption at 1680 and $1665 \mathrm{~cm}^{-1}$ for two carbonyl groups. The proton nuclear magnetic resonance $\left({ }^{1} \mathrm{H}-\mathrm{NMR}\right)$ spectrum of compound 4 displayed two singlet broad signals at $\delta 6.10$ and $10.70 \mathrm{ppm}$, agreeing to the three protons of the one $\mathrm{NH}_{2}$ and one $\mathrm{NH}$ group $\left(\mathrm{D}_{2} \mathrm{O}\right.$-exchangeable). The reaction of the latter compound 4 with sodium ethoxide (NaOEt) afforded the conforming sodium salt, which, upon treatment with acetic anhydride $\left(\mathrm{Ac}_{2} \mathrm{O}\right)$, provided the acetylated (5). In another way, the acetylated of compound 4 with acetic anhydride, itself, for one hour formed the $\mathrm{N}$-(4-(3-acetyl- 6-benzoyl-7-methyl-8-oxo-3,8dihydrothieno[2,3-d][1,2,4]triazolo[1,5-a]pyrimidin-2-yl) phenyl) acetamide (5) in 74\% yield. The ${ }^{1} \mathrm{H}-\mathrm{NMR}$ spectrum of compound 5 demonstrated one singlet broad signal at $11.90 \mathrm{ppm}$, correspondent to the one proton of the one $\mathrm{NH}$ group with $\mathrm{D}_{2} \mathrm{O}$-exchangeable. Moreover, refluxing 2,3-diamino-benzoyl-methylthieno- pyrimidinone (3) with a proper aromatic aldehyde, namely benzaldehyde, 4-chloro- benzaldehyde or 4-methoxybenzaldehyde, respectively, in dimethylformamide solution, having a catalyst amount of potassium iodide for an extended time, gave the products 6-benzoyl-2-(4-substituted-phenyl)-7-methylthieno[2,3d] $[1,2,4]$ triazolo[1,5-a]pyrimidin- $8(3 \mathrm{H})$-one $(\mathbf{6 a}-\mathbf{c})$ in good yields. The ${ }^{1} \mathrm{H}-\mathrm{NMR}$ spectrum of compound $6 \mathbf{a}$ established one singlet broad signal at $\delta 10.55 \mathrm{ppm}$, corresponding to the one proton of $\mathrm{NH}$ group with $\mathrm{D}_{2} \mathrm{O}$-exchangeable. The mass spectra of compounds $\mathbf{6 a}-\mathrm{c}$ showed molecular ion peaks at $\mathrm{m} / \mathrm{z} 386\left(\mathrm{M}^{+}, 90 \%\right), 420\left(\mathrm{M}^{+}, 100 \%\right)$ and $416\left(\mathrm{M}^{+}, 95 \%\right)$, respectively, as shown in Scheme 1. 


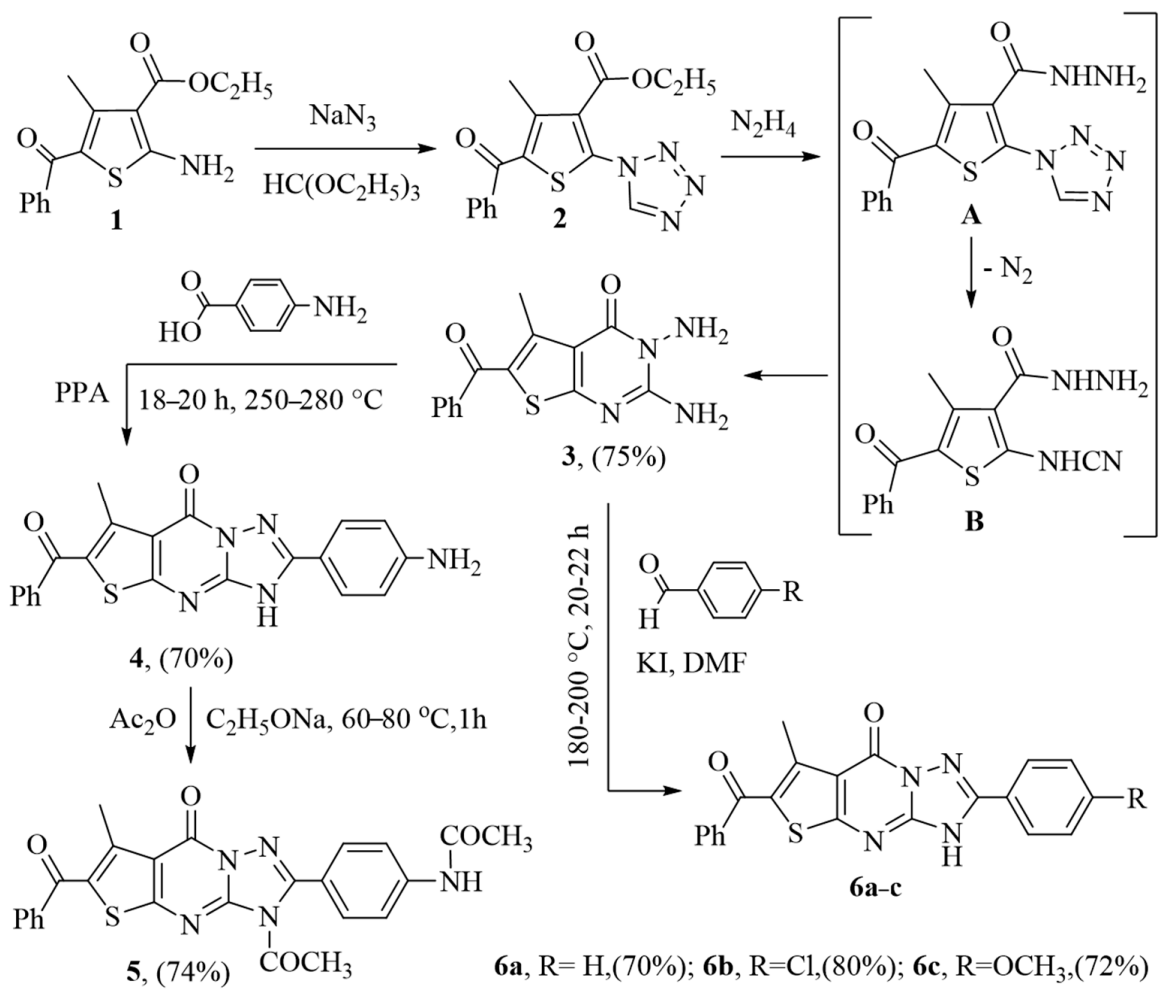

Scheme 1. Synthesis of 2-(sub)-thieno[2,3-d][1,2,4]triazolopyrimidinone derivatives.

Heating of 2,3-diamino-benzoyl-methylthienopyrimidinone (3) with methylphenylcarbamodithioate and red mercury (II) oxide $(\mathrm{HgO})$ catalyzed in dimethylformamide to give 6-benzoyl-7-methyl-2-(phenylamino)thieno[2,3-d][1,2,4]triazolo[1,5-a]pyrimidin-8 (3H)-one (7) in good yield. IR spectrum of compound 7 revealed the presence of broad bands absorption at 3360 and $3320 \mathrm{~cm}^{-1}$ of (2NH) groups and 1715 and $1676 \mathrm{~cm}^{-1}$ of two carbonyl groups, and ${ }^{1} \mathrm{H}-\mathrm{NMR}$ spectrum of compound 7 displayed two singlet broad signals at $\delta 9.60$ and $10.80 \mathrm{ppm}$, conforming to the two protons of the (2NH) groups with $\mathrm{D}_{2} \mathrm{O}$-exchangeable. Moreover, 6-benzoyl-7-methylthieno[2,3- $\left.d\right][1,2,4]$ triazolo[1,5a]pyri- midine-2,8 $(1 \mathrm{H}, 3 \mathrm{H})$-dione (8) was prepared by reacting of 2,3-diamino-benzoylmethyl- thienopyrimidinone (3) with ethyl-chloroformate and anhydrous potassium carbonate in dry acetone. IR spectra of compound 8 showed the absence of some absorption bands for two amino groups, with the presence of bands absorption at 3352 and $3310 \mathrm{~cm}^{-1}$ of (2NH) groups and 1722, $16851674 \mathrm{~cm}^{-1}$ of three carbonyl groups. The ${ }^{1} \mathrm{H}-\mathrm{NMR}$ spectrum of compound 8 designated two singlet broad signals at $\delta 10.20$ and $11.10 \mathrm{ppm}$, corresponding to the two protons of the $(2 \mathrm{NH})$ groups. On the other hand, heating and stirring of 2,3-diamino-benzoyl-methylthienopyrimidinone (3) with carbon disulfide in an methanolic potassium hydroxide solution led to the formation of 6-benzoyl-2-mercapto-7-methylthieno[2,3-d][1,2,4]triazolo[1,5-a]pyrimidin-8(3H)-one (9). IR spectra of compound 9 presented the presence of broad bands absorption at 3345 and $2372 \mathrm{~cm}^{-1}$ of $(\mathrm{NH})$ and $(\mathrm{SH})$ groups, respectively, and ${ }^{1} \mathrm{H}-\mathrm{NMR}$ spectrum of compound 9 revealed two singlet signals at 2.62 and $9.05 \mathrm{ppm}$, agreeing to two protons of the $(\mathrm{SH})$ and $(\mathrm{NH})$ groups with $\mathrm{D}_{2} \mathrm{O}$-exchangeable, respectively. In addition, the reaction of 2,3-diamino-benzoyl-methylthienopyrimidinone (3) with chloroacetic acid in hydrochloric acid $(4 \mathrm{~N}, \mathrm{HCl})$ produced the 6-benzoyl-2-(chloromethyl)-7-methylthieno[2,3d][1,2,4] triazolo[1, 5-a] pyrimidin-8 (3H)-one (10). IR spectra of compound (10) obtained the presence of bands absorption at $3341 \mathrm{~cm}^{-1}$ of (NH) and 1724 and $1680 \mathrm{~cm}^{-1}$ of two carbonyl groups, and ${ }^{1} \mathrm{H}-\mathrm{NMR}$ spectrum of compound 10 discovered one singlet signal at $9.15 \mathrm{ppm}$, conforming to the one proton of the $(\mathrm{NH})$ group $\left(\mathrm{D}_{2} \mathrm{O}-\right.$ exchangeable). Thus, the heating under reflux of 2-mercapto-thienotriazolopyrimidinone (9) with 2-(chloromethyl)- 
thienotriazolopyrimi- dinone (10) in an methanolic sodium metal solution produced the 6-benzoyl-2-(((6-ben- zoyl-7-methyl-8-oxo-3,8-dihydrothieno[2,3-d][1,2,4]triazolo[1,5a]pyrimidin-2-yl)methyl)thio)-7-methylthieno[2,3-d][1,2,4]triazolo[1,5-a]pyrimidin- $8(3 \mathrm{H})$ one (11). The ${ }^{1} \mathrm{H}-\mathrm{NMR}$ spectra of compound 11 exhibited two broad singlet signals at $\delta$ 9.80 and $10.10 \mathrm{ppm}$, identical to the two protons of the $(2 \mathrm{NH})$ groups $\left(\mathrm{D}_{2} \mathrm{O}\right.$-exchangeable). Mass spectra of compounds (7- 11) showed molecular ion peaks at m/z $401\left(\mathrm{M}^{+}, 95 \%\right), 326$ $\left(\mathrm{M}^{+}, 100 \%\right), 342\left(\mathrm{M}^{+}, 93 \%\right), 358\left(\mathrm{M}^{+}, 91 \%\right)$ and $664\left(\mathrm{M}^{+}, 90 \%\right)$, respectively as shown in Scheme 2 .

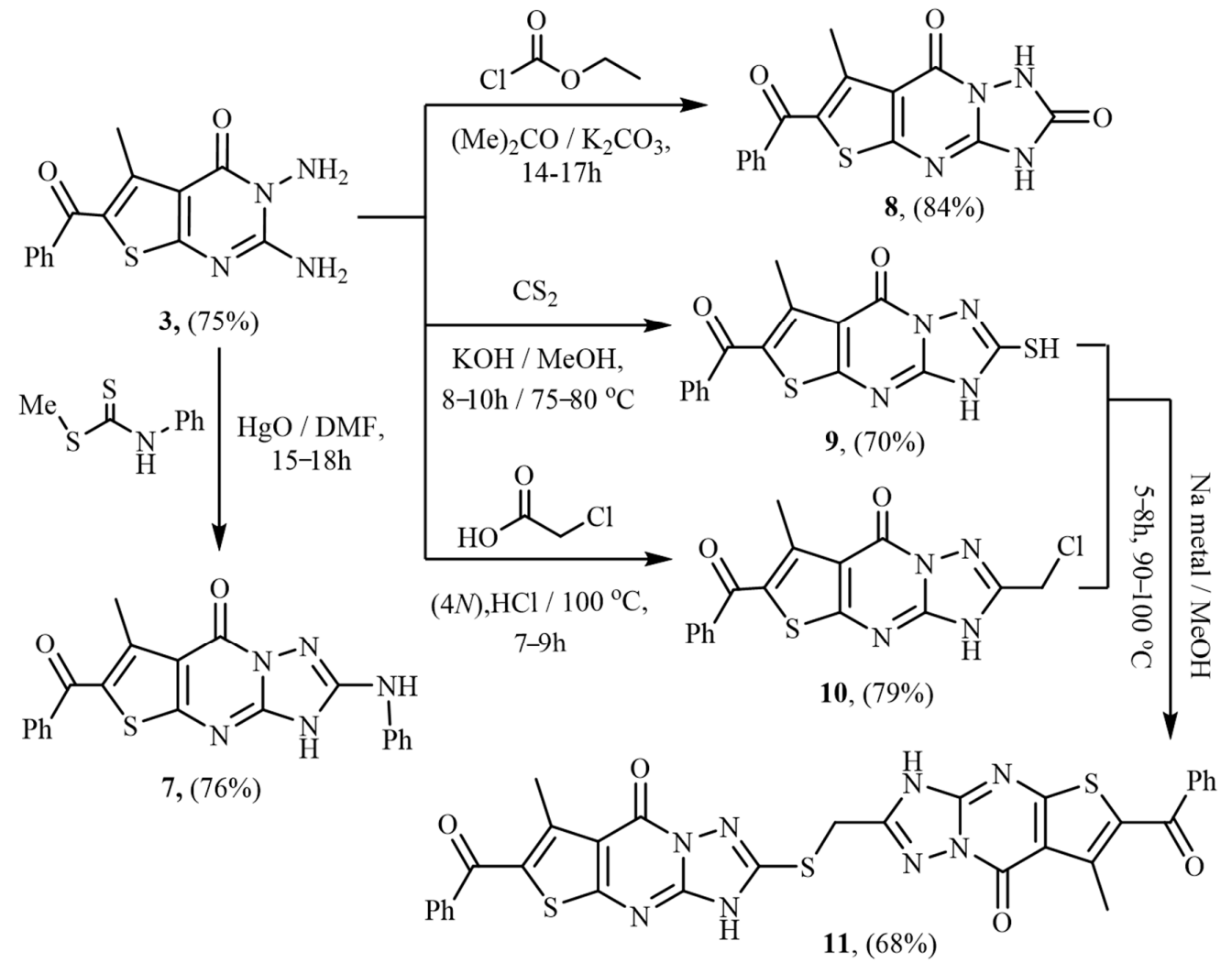

Scheme 2. Synthesis of methylthieno[2,3-d][1,2,4] triazolo[1,5-a]pyrimidinone derivatives.

In addition, 6-benzoyl-2-(mercaptomethyl)-7-methylthieno[2,3-d][1,2,4]triazolo[1,5a]pyrimidin-8 (1H)-one (12) was synthesized from 2,3-diamino-benzoyl-methylthienopyrimidinone (3) and mercaptoacetic acid, when refluxed in absolute ethanol. IR spectrum of compound (12) revealed absorption bands at 3370, 2355, 1730 and $1675 \mathrm{~cm}^{-1}$ of $(\mathrm{NH}),(\mathrm{SH})$ and two carbonyl groups, respectively. The ${ }^{13} \mathrm{C}-\mathrm{NMR}$ spectra of compound (12) displayed signals at $\delta 20.3$ and $30.1 \mathrm{ppm}$, agreeing to the two carbon atoms of $\mathrm{CH}_{3}$ and $\mathrm{CH}_{2}$ groups, and also at 166.4 and $181.2 \mathrm{ppm}$, matching the two carbon atoms of the two carbonyl groups. Moreover, Alkylation of thienotriazolopyrimidinone (12), in dry dimethylormamide and potassium hydroxide solution with ethylbromoacetate, afforded 2-benzoyl-3-methylthieno[ $\left[2^{\prime \prime}, 3^{\prime \prime}: 4^{\prime}, 5^{\prime}\right]$ pyrimido[ $\left[1^{\prime}, 2^{\prime}: 2,3\right][1,2,4]$ triazolo[5,1c] $[1,4]$ thiazine-4,7(8H,10H)-dione (13). ${ }^{13} \mathrm{C}-\mathrm{NMR}$ spectra of compound (13) showed signals at $\delta 20.5,33.2$ and $37.5 \mathrm{ppm}$, correspondent to three carbon atoms of one $\mathrm{CH}_{3}$ and two $\mathrm{CH}_{2}$ groups, respectively, and 165.9, 167.2 and $182.1 \mathrm{ppm}$, identical to three carbon atoms of the three carbonyl groups. In addition, the synthesis of 6-benzoyl-7-methyl-8-oxo-3, 8-dihydrothieno[2,3-d][1,2,4] triazolo[1,5-a]pyrimidine-2-carboxylic acid (14) was synthesized in 72\% yield from 2,3-diamino-benzoyl-methylthienopyrimidinone (3), oxalic acid and anhydrous potassium carbonate in dry dimethylformamide under refluxing conditions for 20-25 h. IR spectra of compound (14) showed absorption bands at 3375 and $3360 \mathrm{~cm}^{-1}$ of $\mathrm{OH}$ and NH groups and 1745,1735 and $1679 \mathrm{~cm}^{-1}$ of three carbonyl groups. The ${ }^{1} \mathrm{H}-\mathrm{NMR}$ spectrum of 
compound (14) displayed two singlet broad signals at $\delta 10.20$ and $12.45 \mathrm{ppm}$, corresponding to the two protons of the $\mathrm{NH}$ and $\mathrm{OH}$ groups (with $\mathrm{D}_{2} \mathrm{O}$-exchangeable), respectively. Furthermore, condensation and cyclization of thienotriazolopyrimidinone (12), oxalic acid with the presence of anhydrous potassium carbonate in dry dimethyl- formamide gave 2-benzoyl-8-hydroxy-9-mercapto-3-methylpyrrolo[ $\left[1^{\prime}, 2^{\prime}: 2,3\right][1,2,4]$ triazolo[1,5-a]thieno[2,3d]pyrimidin-4,7-dione (15). The ${ }^{1} \mathrm{H}-\mathrm{NMR}$ spectrum of compound (15) showed two singlet signals at $\delta 2.70$ and $12.10 \mathrm{ppm}$, agreeing to the two protons of the $\mathrm{SH}$ and $\mathrm{OH}$ groups $\left(\mathrm{D}_{2} \mathrm{O}\right.$-exchangeable). The mass spectrum of compounds 12, 13, 14 and 15 showed molecular ion peaks at $\mathrm{m} / \mathrm{z} 356\left(\mathrm{M}^{+}, 100 \%\right), 396\left(\mathrm{M}^{+}, 95 \%\right), 354\left(\mathrm{M}^{+}, 90 \%\right)$ and $410\left(\mathrm{M}^{+}, 98 \%\right)$, respectively, as shown in Scheme 3.<smiles>CC1=C(C(=O)c2ccccc2)SC2=Nc3nc4n(c3C1=O)C(=O)CSC24</smiles>

13, $(80 \%)$
$-\mathrm{HBr}$
$-\mathrm{EtOH}$<smiles>CCOC(=O)CSCc1nc2nc3sc(C(=O)c4ccccc4)c(C)c3c(=O)n2[nH]1</smiles>

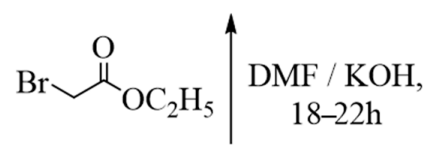<smiles>CCOC(=O)c1sc2nc(N)n(N)c(=O)c2c1C</smiles>
$3,(75 \%)$<smiles>O=C(O)C(=O)O</smiles>
$12,(73 \%)$<smiles>[Y20][Y20](=O)OCCc1nc2nc3sc(C(=O)c4ccccc4)c(C)c3c(=O)n2[nH]1</smiles><smiles>Cc1c(C(=O)c2ccccc2)sc2nc3[nH]c(C(=O)O)nn3c(=O)c12</smiles>

14, $(72 \%)$<smiles>CC1=C(C(=O)c2ccccc2)Sc2nc3nc4c(S)c(O)n(CCO)c4c(=O)n3c1c2C(=O)c1ccccc1</smiles>

Scheme 3. Synthesis of thiazine, pyrrolo-1,2,4-triazolo-thieno[2,3-d]pyrimidinones.

Additionally, the treatment of pyrrolotriazolothienopyrimidine-4,7-dione (15) with $o$-phenylene-diamine in refluxing dimethylformamide and anhydrous potassium carbonate resulted in the formation of 2-benzoyl-3-methyl-8,13-dihydrothieno[ $\left[2^{\prime \prime \prime}, 3^{\prime \prime \prime}: 4^{\prime \prime}, 5^{\prime \prime}\right]$ pyrimido[ $\left[1^{\prime \prime}, 2^{\prime \prime}: 2^{\prime}, 3^{\prime}\right][1,2,4]$ triazolo $\left[1^{\prime}, 5^{\prime}: 1,2\right]$ pyrrolo[3,4-b]quinoxaline-4,7-dione (16). The ${ }^{1} \mathrm{H}$ NMR spectra of compound $\mathbf{1 6}$ exhibited two singlet broad signals at $\delta 11.50$ and $11.57 \mathrm{ppm}$, conforming to the two protons of the two $(2 \mathrm{NH})$ groups $\left(\mathrm{D}_{2} \mathrm{O}\right.$-exchangeable).

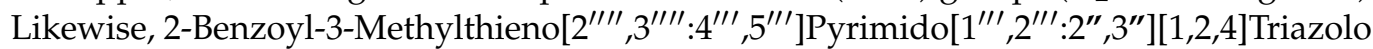
$\left[1^{\prime \prime}, 5^{\prime \prime}: 1^{\prime}, 2^{\prime}\right]$ Pyrrolo[3', $\left.4^{\prime}: 5,6\right][1,4]$ Oxathiino[2,3-b]Quinoxaline-4,7-Dione (17) was synthesized from the reaction of compound 15 with 2,3-dichloroquinoxaline in boiling absolute ethanol with the presence of a catalytic amount of triethylamine. In the ${ }^{13} \mathrm{C}-\mathrm{NMR}$ spectrum of compound 17, it displayed signals at $\delta 166.5,170.9$ and $183.8 \mathrm{ppm}$, due to three carbonyl groups. The pyrrolotriazolothienopyrimidine-4,7-dione (15) also reacted with $\alpha$-halo-ketones as chloroacetyl-chloride in dimethylformamide with the presence of anhy- 
drous potassium carbonate or in acetic acid with the presence of zinc dust to afford the corresponding 8-benzoyl-9-methyl-[1,4] oxathiino $\left[3^{\prime \prime}, 2^{\prime \prime}: 3^{\prime}, 4^{\prime}\right]$ pyrrolo[ $\left[1^{\prime}, 2^{\prime}: 2,3\right][1,2,4]$ triazolo[1,5-a]thieno[2,3-d]pyrimidine-3,10,13 (2H)-trione (18). The ${ }^{1} \mathrm{H}-\mathrm{NMR}$ spectrum of compound 18 showed one singlet signal at $5.10 \mathrm{ppm}$, conforming to the two protons of the $\mathrm{CH}_{2}$, and multiple singlet signals at $\delta 7.61-7.90 \mathrm{ppm}$, agreeing to the five protons of the phenyl group. Moreover, the reaction of pyrrolotriazolothienopyrimidine-4,7-dione (15) with thiourea in a mixture of dimethylformamide or dioxane in the presence of catalytic amount of piperidine under control (TLC) afforded the 7-benzoyl-2-mercapto-8- methyl$1 H$-imidazo[4", $\left.5^{\prime \prime}: 3^{\prime}, 4^{\prime}\right]$ pyrrolo[1', 2':2,3][1,2,4] triazolo[1,5-a]thieno[2,3-d]pyrimidi- ne-9, 12-dione (19). The IR spectrum of compound 19 displayed the presence of broad band absorption at $v 3355 \mathrm{~cm}^{-1}$ of one (NH) group, $2357 \mathrm{~cm}^{-1}$ of one (SH) group and 1729, 1681 and $1670 \mathrm{~cm}^{-1}$ of the three carbonyl groups. The ${ }^{1} \mathrm{H}-\mathrm{NMR}$ spectrum of compound 19 demonstrated two singlet broad signals at $\delta 10.83$ and $11.90 \mathrm{ppm}$, corresponding to the two protons of the $(\mathrm{SH})$ and $(\mathrm{NH})$ groups, respectively $\left(\mathrm{D}_{2} \mathrm{O}\right.$-exchangeable). Furthermore, refluxed 19 with benzo-hydrazide in dry dimethylformamide and anhydrous potassium carbonate formed a new heterocyclic compound, 10- benzoyl-9-methyl-3-phenyl- $1 \mathrm{H}$ $[1,2,4]$ triazolo[ $\left[4^{\prime \prime \prime}, 3^{\prime \prime \prime}: 1^{\prime \prime}, 2^{\prime \prime}\right]$ imidazo $\left[4^{\prime \prime}, 5^{\prime \prime}: 3^{\prime}, 4^{\prime}\right]$ pyrrolo[ $\left[1^{\prime}, 2^{\prime}: 2,3\right][1,2,4]$ triazolo[1,5-a] thie- no [2,3-d]pyrimidine-5,8-dione (20). The ${ }^{1} \mathrm{H}-\mathrm{NMR}$ spectrum of compound 20 revealed one singlet signal at $\delta 12.01 \mathrm{ppm}$ for one proton of $\mathrm{NH}\left(\mathrm{D}_{2} \mathrm{O}\right.$-exchangeable). The mass spectra of compounds 16-20 exhibited the molecular ion peaks at $\mathrm{m} / \mathrm{z} 466\left(\mathrm{M}^{+}, 100 \%\right), 536\left(\mathrm{M}^{+}, 94 \%\right)$, $450\left(\mathrm{M}^{+}, 90 \%\right), 434\left(\mathrm{M}^{+}, 85 \%\right)$ and $518\left(\mathrm{M}^{+}, 100 \%\right)$, respectively, as shown in Scheme 4.<smiles></smiles><smiles>Cc1c(C(=O)c2ccccc2)sc2nc3nc4n(c3c(=O)n12)C(=O)C1=C4SC(=O)CO1</smiles>

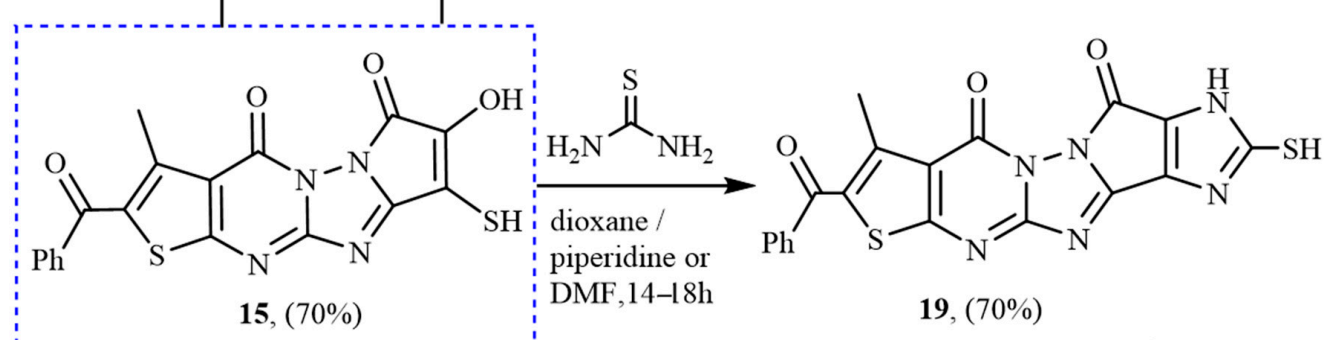

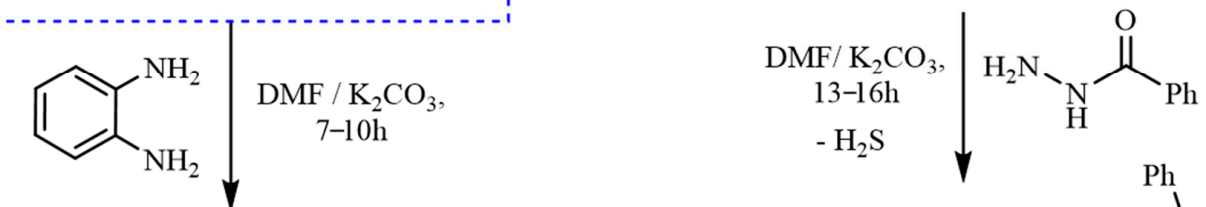<smiles>Cc1c(C(=O)c2ccccc2)sc2nc3nc4c5[nH]c6ccccc6[nH]c=5c(=O)n4c3c(=O)n12</smiles>

$16,(64 \%)$<smiles></smiles>

20, $(73 \%)$

Scheme 4. Synthesis of polycyclic: thienopyrimidotriazolopyrrolo; -quinoxaline, 1,4-oxathiino and imidazole derivatives. 


\subsection{Biological Activities}

\subsubsection{Anticancer Screening (In Vitro Cytotoxicity)}

The new compounds that were synthesized, such as thieno[2,3-d]pyrimidinones, thienotriazolopyrimidinones, thienopyrimido-triazolo-thiazines, pyrrolo-triazolothieno- pyrimidines, thieno-pyrimido-triazolopyrrolo-quinoxalines, thieno-pyrimidotriazolo-pyrrolo-oxathiino-quinoxalines, 1,4-oxathiino-pyrrolotriazolo-thienopyrimidin-triones, imidazopyrrolotriazolothienopyrimidin-diones and 1,2,4-triazoloimidazopyrrolotriazol- othienopyrimidin-diones, were tested for their in vitro cytotoxicity using the standard method to test cell growth rate and toxicity of the culture (MTT) method $[34,38,40,48]$ against the human nasopharyngeal carcinoma cells (CNE2), oral carcinoma cells (KB), breast adenocarcinoma cells (MCF-7) and gastric carcinoma cells (MGC-803). The MTT method is based on the reduction of soluble 3-(4,5dimethyl-2-thiazolyl)-2,5-diphenyl-2H-tetrazolium bromide, as shown in Table 1 . Through the final results of the effect of compounds against the types of human carcinoma cell lines, we found many compounds, such as 20-19, 17-16, 11 and 18 gave the highest anticancer activity. Some of the compounds, 20-19, exhibited the highest effect of cytotoxicity and outperformed the 5-Fluorouracil-positive control. Many compounds had moderate results in activity against cancer cells, such as 15, 5, 7, 13 and 12 and the rest of the compounds in the manuscript, had a weak effect against cancer cells. Consequently, the compounds 20, 19, 17, 16, 11 and 18 possess the best activities against all carcinoma cell lines as follows: the CNE2 ( IC $_{50}$ : Comp. 20-19, 17-16, 11 and $\mathbf{1 8}$ gives 11.6-11.7, 11.8-11.9, 12.1 and 12.4 $\mu \mathrm{M})$; the KB ( $\mathrm{IC}_{50}$ : Comp. 20-19, 17-16, 11 and 18 gives 10.5, 10.7, 10.8-10.9, 11.1 and 11.3 $\mu \mathrm{M}$ ); the MCF-7 ( $\mathrm{IC}_{50}$ : Comp. 20-19, 17-16, 11 and 18 gives 11.3-11.4, 11.5-11.6, 11.8 and $11.9 \mu \mathrm{M}$ ); the MGC-803 ( $\mathrm{IC}_{50}$ : Comp. 20-19, 17-16, 11 and 18 gives 10.9, 11.1, 11.3, 11.5, 11.7 and $11.9 \mu \mathrm{M})$, respectively. All results of the compounds as anticancer activities are mentioned in Table 1.

Table 1. Cytotoxic activity of the new compounds against different human cancer cell lines

\begin{tabular}{ccccc}
\hline \multirow{2}{*}{ Compounds } & \multicolumn{4}{c}{ In Vitro Cytotoxicity $\mathbf{I C}_{\mathbf{5 0}}(\boldsymbol{\mu M} \mathbf{M})$} \\
\cline { 2 - 5 } & $\mathbf{C N E 2}^{\mathbf{a}}$ & $\mathbf{K B}^{\mathbf{a}}$ & $\mathbf{M C F}^{\mathbf{a}}$ & MGC-803 $^{\mathbf{a}}$ \\
\hline $\mathbf{1}$ & $>50$ & $>50$ & $>50$ & $>50$ \\
$\mathbf{2}$ & $>50$ & $>50$ & $>50$ & $>50$ \\
$\mathbf{3}$ & $33.5 \pm 1.8$ & $32.2 \pm 1.2$ & $34.1 \pm 1.3$ & $35.7 \pm 1.5$ \\
$\mathbf{4}$ & $21.3 \pm 1.1$ & $20.5 \pm 1.3$ & $20.9 \pm 1.2$ & $21.5 \pm 1.4$ \\
$\mathbf{5}$ & $13.1 \pm 1.1$ & $12.3 \pm 1.4$ & $12.5 \pm 1.3$ & $12.8 \pm 1.2$ \\
$\mathbf{6 a}$ & $26.3 \pm 1.4$ & $25.8 \pm 1.7$ & $26.9 \pm 1.9$ & $27.5 \pm 1.3$ \\
$\mathbf{6 b}$ & $24.5 \pm 1.5$ & $23.1 \pm 1.2$ & $24.2 \pm 1.4$ & $25.2 \pm 1.1$ \\
$\mathbf{6 c}$ & $25.1 \pm 1.2$ & $24.2 \pm 1.3$ & $25.5 \pm 1.5$ & $26.8 \pm 1.8$ \\
$\mathbf{7}$ & $14.2 \pm 1.7$ & $13.5 \pm 1.5$ & $13.7 \pm 1.1$ & $13.9 \pm 1.4$ \\
$\mathbf{8}$ & $29.1 \pm 1.2$ & $28.7 \pm 1.1$ & $29.5 \pm 1.8$ & $30.2 \pm 1.6$ \\
$\mathbf{9}$ & $18.3 \pm 1.7$ & $17.2 \pm 1.5$ & $17.8 \pm 1.4$ & $18.5 \pm 1.3$ \\
$\mathbf{1 0}$ & $19.1 \pm 1.6$ & $18.4 \pm 1.2$ & $18.7 \pm 1.3$ & $19.2 \pm 1.5$ \\
$\mathbf{1 1}$ & $12.1 \pm 1.2$ & $11.1 \pm 1.3$ & $11.8 \pm 1.5$ & $11.7 \pm 1.4$ \\
$\mathbf{1 2}$ & $16.1 \pm 1.4$ & $15.3 \pm 1.3$ & $15.9 \pm 1.2$ & $16.5 \pm 1.1$ \\
$\mathbf{1 3}$ & $15.4 \pm 1.3$ & $14.1 \pm 1.2$ & $14.8 \pm 1.1$ & $15.7 \pm 1.2$ \\
$\mathbf{1 4}$ & $20.5 \pm 1.8$ & $19.8 \pm 1.5$ & $19.8 \pm 1.4$ & $20.4 \pm 1.6$ \\
$\mathbf{1 5}$ & $12.7 \pm 1.2$ & $11.7 \pm 1.6$ & $12.1 \pm 1.2$ & $12.2 \pm 1.4$ \\
$\mathbf{1 6}$ & $11.9 \pm 1.5$ & $10.9 \pm 1.2$ & $11.6 \pm 1.1$ & $11.5 \pm 1.3$ \\
$\mathbf{1 7}$ & $11.8 \pm 1.4$ & $10.8 \pm 1.1$ & $11.5 \pm 1.4$ & $11.3 \pm 1.5$ \\
$\mathbf{1 8}$ & $12.4 \pm 1.5$ & $11.3 \pm 1.4$ & $11.9 \pm 1.3$ & $11.9 \pm 1.1$ \\
$\mathbf{1 9}$ & $11.7 \pm 1.3$ & $10.7 \pm 1.5$ & $11.4 \pm 1.1$ & $11.1 \pm 1.2$ \\
$\mathbf{2 0}$ & $11.6 \pm 1.1$ & $10.5 \pm 1.5$ & $11.3 \pm 1.2$ & $10.9 \pm 1.4$ \\
$\mathbf{5 - F l u o r o u r a c i l}$ & $11.8 \pm 1.4$ & $10.7 \pm 1.2$ & $11.5 \pm 1.3$ & $11.1 \pm 1.1$ \\
\hline
\end{tabular}

a CNE2 cells are drug-sensitive human nasopharyngeal carcinoma cells; KB cells are drug-sensitive human oral carcinoma cells; MCF-7 cells are drug-sensitive human breast adenocarcinoma cells and MGC-803 cells are drug-sensitive human gastric carcinoma cells. 


\subsubsection{Structural Activity Relationship (SAR)}

The relationship of the chemical structures (SARs) of the prepared compounds to the results mentioned in this study, in terms of the ability of these compounds to apply cytotoxicity activity to human carcinoma cells, is due to several possibilities, including the following: (A) The presence of the thienopyrimidinones, 1,2,4-triazolopyrimidinone, 1,4-thiazine, pyrrolo-1,2,4-triazole, pyrroloquinoxaline, oxathiinoquinoxaline, 1,4-oxathiinopyrrolotriazole, imidazopyrrolotriazole and 1,2,4-triazoloimidazopyrrolo-triazole moieties may be requested for a broad spectrum of the cytotoxicity activity. (B) 1,2,4triazoloimidazopyrrolotriazolothienopyrimidindione (20), imidazopyrrolotriazolo- thienopyrimidindione (19), thienopyrimidotriazolopyrrolooxathiinoquinoxalindione (17), thienopyrimidotriazolopyrroloquinoxalindione (16), 2-((6-benzoyl-thienotriazolo- pyrimidin-2yl)methyl) thio)-thienotriazolopyrimidinene (11) and 1,4-oxathiinopyrrolo- triazolothienopyrimidin-trione (18) demonstrated great anticancer activity in vitro, and this corresponds to previous scientific studies, because numerous heterocyclic compounds have pharmacological activities, such as imidazoles, benzimidazoles, thieno-[2,3-d]pyrimidines, 1,2,4-triazoles, thiazolopyrimidines, pyrrolothiazolo-pyrimidines, pyrrolotriazines, pyrrolotriazepines, triazolopyrrolothiazolopyrimidines, quinolines, quinoxalines, thiazolidinones, thiazines, thienotriazoles, thiophenes, phenyl, benzoyl and methyl, which have displayed potent anticancer activity $[2,5,8,10,20,25,34,38,40,48-50]$. (C) Thence, the compounds 20, 19, 17, 16, 11 and 18 offered high cytotoxicity against all human carcinoma cell lines, such as nasopharyngeal (CNE2), oral (KB), breast (MCF-7) and gastric (MGC-803), during the comparison with 5-Fluorouracil as a standard drug, shown in Table 2. From studying the chemical structures of compounds 20-16 and 11, it becomes clear that these compounds are preferred for the following reasons: (I) they contain thienotriazolopyrimidinene as the basis in these compounds. (II) Some compounds containing pyrrole, imidazole and triazole rings are all linked with the thienotriazolopyrimidinene basis, such as compound 20. (III) Some compounds that contain pyrrole and imidazole rings are all linked with the thienotriazolopyrimidinene basis, such as compound 19. (IV) Some compounds that contain pyrrole, oxathiine and quinoxaline rings are all linked with the thienotriazolopyrimidinene basis, such as compound 17. (V) Some compounds that contain pyrrole and quinoxaline rings are all linked with the thienotriazolopyrimidinene basis, such as compound 16. (VI) Some compounds that contain pyrrole and oxathiine rings are all linked with the thienotriazolopyrimidinene basis, such as compound 18. (VII) Some compounds linked with two molecules of thienotriazolopyrimidinene, such as compound 11. (VIII) These are in addition to many functional groups, such as methyl and phenyl, and many heteroatoms, such as nitrogen, oxygen and sulfur.

Table 2. The best new compounds to cytotoxic activity against different human cancer cell lines.

\begin{tabular}{|c|c|c|c|c|}
\hline \multirow{2}{*}{ Compounds/Chemical Structures } & \multicolumn{4}{|c|}{ In Vitro Cytotoxicity $\mathrm{IC}_{50}(\mu \mathrm{M})$} \\
\hline & CNE2 ${ }^{a}$ & $\mathrm{~KB}^{\mathbf{a}}$ & MCF-7 ${ }^{a}$ & MGC-803 ${ }^{\text {a }}$ \\
\hline & $12.1 \pm 1.2$ & $11.1 \pm 1.3$ & $11.8 \pm 1.5$ & $11.7 \pm 1.4$ \\
\hline & $11.9 \pm 1.5$ & $10.9 \pm 1.2$ & $11.6 \pm 1.1$ & $11.5 \pm 1.3$ \\
\hline & & & & \\
\hline
\end{tabular}


Table 2. Cont.

\begin{tabular}{|c|c|c|c|c|}
\hline \multirow{2}{*}{ Compounds/Chemical Structures } & \multicolumn{4}{|c|}{ In Vitro Cytotoxicity $\mathrm{IC}_{50}(\mu \mathrm{M})$} \\
\hline & CNE2 ${ }^{a}$ & $K_{B}{ }^{a}$ & MCF-7 $^{a}$ & MGC-803 ${ }^{\text {a }}$ \\
\hline & $11.8 \pm 1.4$ & $10.8 \pm 1.1$ & $11.5 \pm 1.4$ & $11.3 \pm 1.5$ \\
\hline & $12.4 \pm 1.5$ & $11.3 \pm 1.4$ & $11.9 \pm 1.3$ & $11.9 \pm 1.1$ \\
\hline & $11.7 \pm 1.3$ & $10.7 \pm 1.5$ & $11.4 \pm 1.1$ & $11.1 \pm 1.2$ \\
\hline & $11.6 \pm 1.1$ & $10.5 \pm 1.5$ & $11.3 \pm 1.2$ & $10.9 \pm 1.4$ \\
\hline & $11.8 \pm 1.4$ & $10.7 \pm 1.2$ & $11.5 \pm 1.3$ & $11.1 \pm 1.1$ \\
\hline & & & & \\
\hline
\end{tabular}

${ }^{\text {a }}$ CNE2 cells are drug-sensitive human nasopharyngeal carcinoma cells; KB cells are drug-sensitive human oral carcinoma cells; MCF-7 cells are drug-sensitive human breast adenocarcinoma cells and MGC-803 cells are drug-sensitive human gastric carcinoma cells.

\section{Experimental Section}

\subsection{General Information}

All melting points were taken on an Electrothermal IA 9100 series digital melting point apparatus (Shimadzu, Tokyo, Japan). Elemental analyses were performed on Vario EL (Elementar, Langenselbold, Germany). Microanalytical data were processed in the microanalytical center, Faculty of Science, Cairo University and National Research Centre. The IR spectra (KBr disc) were recorded using a Perkin-Elmer 1650 spectrometer (Waltham, MA, USA). NMR spectra were determined using JEOL $270 \mathrm{MHz}$ and JEOL JMS-AX $500 \mathrm{MHz}$ (JEOL, Tokyo, Japan) spectrometers with Me4Si as an internal standard. Mass spectra were recorded on an EI Ms-QP 1000 EX instrument (Shimadzu, Tokyo, Japan) at 70 eV. Biological evaluations were done by the anticancer unit, Mansoura University, Faculty of Pharmacy (Department of Pharmacognosy), 35516, Egypt. All starting materials and solvents were purchased from Sigma-Aldrich (Saint Louis, MO, USA).

\subsection{Synthesis of 2,3-Diamino-6-Benzoyl-5-Methylthieno[2,3-d]Pyrimidin-4(3H)-One (3)}

Compound 2 ( $3.42 \mathrm{~g}, 0.01 \mathrm{~mol})$ in $15 \mathrm{~mL}$ of hydrazine hydrate was heated under reflux for $7 \mathrm{~h}$. The reaction mixture was cooled and suspended in $50 \mathrm{~mL}$ of water. The solid was collected by suction filtration, washed with water, and recrystallized from ethanol to afford compound $3(75 \%)$. M. p.: $270-272{ }^{\circ} \mathrm{C}$. IR $(\mathrm{KBr}): v_{\max }=3400,3385\left(2 \mathrm{NH}_{2}\right), 1650,1622$ (2CO), $1585(\mathrm{C}=\mathrm{N}) \mathrm{cm}^{-1} ;{ }^{1} \mathrm{H}-\mathrm{NMR}\left(500 \mathrm{MHz}, \mathrm{DMSO}-d_{6}\right): \delta=2.20\left(\mathrm{~s}, 3 \mathrm{H}, \mathrm{CH}_{3}\right), 6.41$ (br. s, 
2H, $\mathrm{CNH}_{2}$ ), 7.43-7.94 (m, 5H, Ar-H), 11.49 (br. s, 2H, NNH 2$)$ ppm; ${ }^{13} \mathrm{C}-\mathrm{NMR}(125.7 \mathrm{MHz}$, DMSO- $\left.d_{6}\right): \delta=19.2,121.3,128.6,129.3,131.5,132.3,135.3,142.2,146.4,149.5,158.1,168.9$ ppm; MS (70 eV): m/z = $300\left(\mathrm{M}^{+}, 100 \%\right)$; Anal. Calc. (Found) for $\mathrm{C}_{14} \mathrm{H}_{12} \mathrm{~N}_{4} \mathrm{O}_{2} \mathrm{~S}$ (300.34): C, 55.99 (55.90); H, 4.03 (4.10); N, 18.66 (18.60).

\subsection{Synthesis of}

2-(4-Aminophenyl)-6-Benzoyl-7-Methylthieno[2,3-d][1,2,4]Triazolo[1,5-a]Pyrimidin-8(3H)-One (4)

Equimolar quantities of 2,3-diamino-benzoyl-methylthienopyrimidinone (3) (3 g, $0.01 \mathrm{~mol})$ and 4-aminobenzoic acid $(1.37 \mathrm{~g}, 0.01 \mathrm{~mol})$ were dissolved in polyphosphoric acid $(30 \mathrm{~mL})$ and refluxed for $18-20 \mathrm{~h}$ at $250-280^{\circ} \mathrm{C}$ under control (TLC), with constant stirring. The reaction mixtures were cooled and slowly poured into crushed ice with constant stirring. The $\mathrm{pH}$ of the reaction mixture was detected to alkaline by adding $4 \mathrm{~N}$ of anhydrous sodium carbonate. The final precipitates were filtered under pressure, washed with distilled water and recrystallized from ethanol as yellow crystals in $70 \%$ yield, $\mathrm{m}$. p. $>350{ }^{\circ} \mathrm{C}$. IR $(\mathrm{KBr}): v_{\max }=3405,3355\left(\mathrm{NH}_{2}, \mathrm{NH}\right), 3045(\mathrm{CH}$, aryl $), 2940(\mathrm{CH}$, alkyl), 1680, $1665(2 \mathrm{C}=\mathrm{O}), 1620(\mathrm{C}=\mathrm{N}), 1585(\mathrm{C}=\mathrm{C}) \mathrm{cm}^{-1} ;{ }^{1} \mathrm{H}-\mathrm{NMR}\left(\mathrm{DMSO}-d_{6}\right): \delta=2.10(\mathrm{~s}, 3 \mathrm{H}$, $\mathrm{CH}_{3}$ ), 6.10 (br. s, 2H, NH 2 ), 7.50-7.90 (m, 9H, Ar-H), 10.70 (br,1H, NH, D $\mathrm{D}_{2}$-exchangeable); ${ }^{13} \mathrm{C}-\mathrm{NMR}\left(\mathrm{DMSO}-d_{6}\right) \delta=20.4\left(1 \mathrm{C}, \mathrm{CH}_{3}\right), 115.1,119.4,121.3,127.1,128.5,129.9,131.5,135.7$, $140.9,143.1,147.2,148.5,151.8,162.9$ (18C, Ar-C), 165.1, 181.4 (2C, 2C=O); MS (70 eV): $\mathrm{m} / \mathrm{z}=401\left(\mathrm{M}^{+}, 100 \%\right)$; Anal. Calc. (Found) for $\mathrm{C}_{21} \mathrm{H}_{15} \mathrm{~N}_{5} \mathrm{O}_{2} \mathrm{~S}$ (401.44): C, 62.83 (62.75); H, 3.77 (3.70); N, 17.45 (17.64).

\subsection{Synthesis of N-(4-(3-Acetyl-6-Benzoyl-7-Methyl-8-oxo-3,8-Dihydrothieno[2,3-d][1,2,4]} Triazolo[1,5-a]Pyrimidin-2-yl)Phenyl) Acetamide (5)

Method A: To a warm $\left(60-80^{\circ} \mathrm{C}\right)$ solution of sodium ethoxide (prepared by dissolving $0.23 \mathrm{~g}$ of sodium metal in $35 \mathrm{~mL}$ ethanol), compound $4(4.01 \mathrm{~g}, 10 \mathrm{mmol})$ was added, and heating $\left(60-80^{\circ} \mathrm{C}\right)$ was continued for $40 \mathrm{~min}$. The mixture was allowed to cool to room temperature, and acetic anhydride $(10 \mathrm{mmol})$ was added. The mixture was stirred under reflux for $8-10 \mathrm{~h}$, allowed to cool to room temperature and finally poured into $100 \mathrm{~mL}$ cold water. The solid product precipitate was filtered off and washed with $100 \mathrm{~mL}$ water. The solid obtained was filtered off, dried and crystallized from the proper solvent to produce compound 5. Method B: A mix of compound 4 (4.01 g, $0.01 \mathrm{~mol})$ and acetic anhydride $(30 \mathrm{~mL})$ was refluxed with heat for one hour, checked via (TLC). After cooling, the solution was concentrated and poured into crushed ice. The separated solid was filtered off, dried and recrystallized from benzene as yellowish crystals in $74 \%$ yield, m. p. $>350{ }^{\circ} \mathrm{C}$. IR $(\mathrm{KBr}): v_{\max }=3325(\mathrm{NH}), 3040(\mathrm{CH}$, aryl $), 2935$ (CH, alkyl), 1705, 1685, 1680, $1675(4 \mathrm{C}=\mathrm{O})$, $1622(\mathrm{C}=\mathrm{N}), 1580(\mathrm{C}=\mathrm{C}) \mathrm{cm}^{-1},{ }^{1} \mathrm{H}-\mathrm{NMR}\left(\mathrm{DMSO}-d_{6}\right): \delta=1.90,2.05,2.15\left(3 \mathrm{~s}, 9 \mathrm{H}, 3 \mathrm{CH}_{3}\right)$, 7.52-7.93 (m, 9H, Ar-H), 11.90 (br, s.1H, NH, D $2 \mathrm{O}-$ exchangeable); ${ }^{13} \mathrm{C}-\mathrm{NMR}$ (DMSO- $d_{6}$ ) mboxemph $\delta=20.7,22.5,26.3\left(3 \mathrm{C}, 3 \mathrm{CH}_{3}\right), 118.8,122.1,123.4,126.7,128.6,129.5,132.2,136.8$, 139.5, 141.4, 143.7, 148.5, 152.2, 163.5 (18C, Ar-C), 164.8, 169.2, 175.1, 182.7 (4C, 4C=O); MS (70 eV): $\mathrm{m} / \mathrm{z}=485\left(\mathrm{M}^{+}, 100 \%\right)$; Anal. Calc. (Found) for $\mathrm{C}_{25} \mathrm{H}_{19} \mathrm{~N}_{5} \mathrm{O}_{4} \mathrm{~S}$ (485.52): $\mathrm{C}, 61.85$ (61.77); H, 3.94 (3.85); N, 14.42 (14.51).

3.5. General Procedure for Synthesis of 6-Benzoyl-2-(4-Substituted-Phenyl)-7-Methylthieno[2,3d][1,2,4]Triazolo[1,5-a]Pyrimidin-8(3H)-One (6a-c)

A mixture of 2,3-diamino-benzoyl-methylthienopyrimidinone (3) ( $3 \mathrm{~g}, 0.01 \mathrm{~mol})$, the appropriate aromatic aldehyde $(0.01 \mathrm{~mol})$ and the catalytic amount of potassium iodide $(0.3 \mathrm{~g}, 0.002 \mathrm{~mol})$ in dimethyl- formamide $(40 \mathrm{~mL})$ was heated and refluxed for $20-22 \mathrm{~h}$ at 180-200 ${ }^{\circ} \mathrm{C}$; the progress of reaction was monitored by TLC, and, at the end of reaction, the solvent was allowed to cool to room temperature and poured into water $(100 \mathrm{~mL})$. Then the obtained solid products were filtered off, dried and crystallized from the appropriate solvent to give compounds $\mathbf{6 a}-\mathbf{c}$ in good yields, respectively. 
3.6. Synthesis of

6-Benzoyl-7-Methyl-2-Phenylthieno[2,3-d][1,2,4]Triazolo[1,5-a]Pyrimidin-8(3H)-One (6a)

The compound was obtained from the reaction of compound 3 and benzaldehyde $(1.06 \mathrm{~g}, 0.01 \mathrm{~mol})$ with DMF/KI, as white crystals, crystallized from dioxane in $70 \%$ yield, $\mathrm{m}$. p. $>350{ }^{\circ} \mathrm{C}$. IR $(\mathrm{KBr}): v_{\max }=3350(\mathrm{NH}), 3060(\mathrm{CH}, \operatorname{aryl}), 2937(\mathrm{CH}$, alkyl $), 1710,1672(2 \mathrm{C}=\mathrm{O})$, $1628(\mathrm{C}=\mathrm{N}), 1580(\mathrm{C}=\mathrm{C}) \mathrm{cm}^{-1} ;{ }^{1} \mathrm{H}-\mathrm{NMR}\left(\mathrm{DMSO}-d_{6}\right): \delta=2.17\left(\mathrm{~s}, 3 \mathrm{H}, \mathrm{CH}_{3}\right), 7.40-7.84(\mathrm{~m}$, 10H, Ar-H), 10.55 (br,1H, NH, D 2 -exchangeable); ${ }^{13} \mathrm{C}-\mathrm{NMR}$ (DMSO-d $\left.{ }_{6}\right) \delta=20.2(1 \mathrm{C}$, $\left.\mathrm{CH}_{3}\right), 121.2,128.1,128.6,128.7,128.9,129.5,130.4,132.1,138.7,142.4,143.6,148.5,151.9$, 162.2 (18C, Ar-C), 164.9, 182.7 (2C, 2C=O); MS (70 eV): $\mathrm{m} / \mathrm{z}=386\left(\mathrm{M}^{+}, 90 \%\right)$; Anal. Calc. (Found) for $\mathrm{C}_{21} \mathrm{H}_{14} \mathrm{~N}_{4} \mathrm{O}_{2} \mathrm{~S}$ (386.43): C, 65.27 (65.20); H, 3.65 (3.74); N, 14.50 (14.40).

3.7. Synthesis of

6-Benzoyl-2-(4-Chlorophenyl)-7-Methylthieno[2,3-d][1,2,4]Triazolo[1,5-a]Pyrimidin-8(3H)-One (6b)

The compound was obtained from the reaction of compound 3 and 4-chlorobenzaldehyde $(1.40 \mathrm{~g}, 0.01 \mathrm{~mol})$ with DMF/KI, as white crystals, crystallized from methanol in $80 \%$ yield, $\mathrm{m}$. p. $>350{ }^{\circ} \mathrm{C}$. IR $(\mathrm{KBr}): v_{\max }=3355(\mathrm{NH}), 3065(\mathrm{CH}, \operatorname{aryl}), 2940(\mathrm{CH}$, alkyl $), 1715,1670(2 \mathrm{C}=\mathrm{O})$, $1630(\mathrm{C}=\mathrm{N}), 1582(\mathrm{C}=\mathrm{C}) \mathrm{cm}^{-1},{ }^{1} \mathrm{H}-\mathrm{NMR}\left(\mathrm{DMSO}-d_{6}\right): \delta=2.20\left(\mathrm{~s}, 3 \mathrm{H}, \mathrm{CH}_{3}\right), 7.35-7.41$ (dd, $2 \mathrm{H}, \mathrm{J}=7.50,7.53 \mathrm{~Hz}$, 4-chlorophenyl), 7.46-7.52 (dd, 2H, J = 7.54, 7.58 Hz, 4-chlorophenyl), 7.62-7.90 (m, 5H, Ar-H), 10.66 (br,1H, NH, D 2 O-exchangeable); ${ }^{13} \mathrm{C}-\mathrm{NMR}$ (DMSO- $\left.d_{6}\right) \delta=20.5$ $\left(1 \mathrm{C}, \mathrm{CH}_{3}\right), 121.7,126.8,128.5,128.7,129.4,129.7,132.3,135.6,137.1,142.3,143.2,148.7,152.3$, 163.1 (18C, Ar-C), 165.5, $183.1(2 \mathrm{C}, 2 \mathrm{C}=\mathrm{O}) ; \mathrm{MS}(70 \mathrm{eV}): \mathrm{m} / \mathrm{z}=420\left(\mathrm{M}^{+}, 100 \%\right)$; Anal. Calc. (Found) for $\mathrm{C}_{21} \mathrm{H}_{13} \mathrm{ClN}_{4} \mathrm{O}_{2} \mathrm{~S}$ (420.87): C, 59.93 (59.85); H, 3.11 (3.19); N, 13.31 (13.39).

3.8. Synthesis of 6-Benzoyl-2-(4-Methoxyphenyl)-7-Methylthieno[2,3-d][1,2,4]Triazolo[1,5a]Pyrimidin-8(3H)-One (6c)

The compound was obtained from the reaction of compound 3 and 4-methoxy- benzaldehyde $(1.36 \mathrm{~g}, 0.01 \mathrm{~mol})$ with $\mathrm{DMF} / \mathrm{KI}$, as yellowish crystals, crystallized from benzene in $72 \%$ yield, m. p. $>350{ }^{\circ} \mathrm{C}$. IR $(\mathrm{KBr}): v_{\max }=3358(\mathrm{NH}), 3067(\mathrm{CH}$, aryl $), 2945(\mathrm{CH}$, alkyl $)$, 1718, $1674(2 \mathrm{C}=\mathrm{O}), 1633(\mathrm{C}=\mathrm{N}), 1585(\mathrm{C}=\mathrm{C}) \mathrm{cm}^{-1} ;{ }^{1} \mathrm{H}-\mathrm{NMR}$ (DMSO-d $\left.{ }_{6}\right): \delta=2.25(\mathrm{~s}, 3 \mathrm{H}$, $\left.\mathrm{CH}_{3}\right), 3.75\left(\mathrm{~s}, 3 \mathrm{H}, \mathrm{OCH}_{3}\right), 7.05-7.12(\mathrm{dd}, 2 \mathrm{H}, \mathrm{J}=7.51,7.54 \mathrm{~Hz}, 4-$ methoxyphenyl), 7.32-7.39 (dd, 2H, J = 7.56, 7.59 Hz, 4- methoxyphenyl), 7.65-7.95 (m, 5H, Ar-H), 10.72 (br,1H, NH, $\mathrm{D}_{2} \mathrm{O}$-exchangeable); ${ }^{13} \mathrm{C}-\mathrm{NMR}\left(\mathrm{DMSO}-d_{6}\right) \delta=21.1,58.4\left(2 \mathrm{C}, 2 \mathrm{CH}_{3}\right), 121.9,122.2,124.5$, $128.4,128.9,129.8,132.5,136.7,142.3,143.6,148.2,152.5,161.3,163.4$, (18C, Ar-C), 166.1, $183.8(2 \mathrm{C}, 2 \mathrm{C}=\mathrm{O})$; $\mathrm{MS}(70 \mathrm{eV}): \mathrm{m} / \mathrm{z}=416\left(\mathrm{M}^{+}, 95 \%\right)$; Anal. Calc. (Found) for $\mathrm{C}_{22} \mathrm{H}_{16} \mathrm{~N}_{4} \mathrm{O}_{3} \mathrm{~S}$ (416.45): C, 63.45 (63.52); H, 3.87 (3.79); N, 13.45 (13.37).

\subsection{Synthesis of}

6-Benzoyl-7-Methyl-2-(Phenylamino)Thieno[2,3-d][1,2,4]Triazolo[1,5-a]Pyrimidin-8(3H)-One (7)

To a suspension of 2,3-diamino-benzoyl-methylthienopyrimidinone (3) (3 g, $0.01 \mathrm{~mol})$ and red mercury (II) oxide $(2.16 \mathrm{~g}, 0.01 \mathrm{~mol})$ in $40 \mathrm{~mL}$ of dimethylformamide was added $1.83 \mathrm{~g}, 0.01 \mathrm{~mol}$, of the corresponding methylphenylcarbamodithioate in $5 \mathrm{~mL}$ of DMF at room temperature. The mixture was refluxed for 15-18 h under control (TLC). After cooling, the mixture was filtrated, and to the filtrate were added $50 \mathrm{~mL}$ of water. The precipitate thus obtained was filtrated off, washed with water, dried and recrystallized from dioxane in $76 \%$ yield as yellow crystals, m. p. $>350{ }^{\circ} \mathrm{C}$. IR $(\mathrm{KBr}): v_{\max }=3360,3320$ (2NH), 3065 (CH, aryl), 2940 (CH, alkyl), 1715, $1676(2 \mathrm{C}=\mathrm{O}), 1630(\mathrm{C}=\mathrm{N}), 1585(\mathrm{C}=\mathrm{C}) \mathrm{cm}^{-1}$; ${ }^{1} \mathrm{H}-\mathrm{NMR}\left(\mathrm{DMSO}-d_{6}\right): \delta=2.20\left(\mathrm{~s}, 3 \mathrm{H}, \mathrm{CH}_{3}\right), 7.15-7.80(\mathrm{~m}, 10 \mathrm{H}, \mathrm{Ar}-\mathrm{H}), 9.60,10.80(\mathrm{br}, 2 \mathrm{H}$, 2NH, $\mathrm{D}_{2} \mathrm{O}$-exchangeable); ${ }^{13} \mathrm{C}-\mathrm{NMR}$ (DMSO- $\left.d_{6}\right) \delta=20.7\left(1 \mathrm{C}, \mathrm{CH}_{3}\right), 120.8,122.1,123.4$, $128.7,129.2,129.8,131.6,137.5,137.9,142.4,143.1,143.9,152.3,161.9$ (18C, Ar-C), 163.8, $181.4(2 \mathrm{C}, 2 \mathrm{C}=\mathrm{O})$; $\mathrm{MS}(70 \mathrm{eV}): \mathrm{m} / \mathrm{z}=401\left(\mathrm{M}^{+}, 95 \%\right)$; Anal. Calc. (Found) for $\mathrm{C}_{21} \mathrm{H}_{15} \mathrm{~N}_{5} \mathrm{O}_{2} \mathrm{~S}$ (401.44): C, 62.83 (62.75); H, 3.77 (3.70); N, 17.45 (17.52). 
3.10. Synthesis of

6-Benzoyl-7-Methylthieno[2,3-d][1,2,4]Triazolo[1,5-a]Pyrimidine-2,8(1H,3H)-Dione (8)

To a solution of 2,3-diamino-benzoyl-methylthienopyrimidinone (3) (3 g, $0.01 \mathrm{~mol})$ and anhydrous potassium carbonate $(1.4 \mathrm{~g}, 0.01 \mathrm{~mol})$ in dry acetone $(50 \mathrm{~mL})$, ethyl- chloroformate $(1 \mathrm{~mL}, 0.01 \mathrm{~mol})$ was added to the solution dropwise; after the completion of the addition, the mixture was refluxed for 14-17 h, allowed to cool at room temperature, and then poured into the cool water. The final product was obtained by being filtrated off, washed with ethanol and recrystallized from methanol in $84 \%$ yield as yellowish crystals, m. p. $>350{ }^{\circ} \mathrm{C}$. IR (KBr): $v_{\max }=3352,3310(2 \mathrm{NH}), 3050(\mathrm{CH}$, aryl $), 2945(\mathrm{CH}$, alkyl), 1722, 1685, $1674(3 \mathrm{C}=\mathrm{O}), 1632(\mathrm{C}=\mathrm{N}), 1588(\mathrm{C}=\mathrm{C}) \mathrm{cm}^{-1} ;{ }^{1} \mathrm{H}-\mathrm{NMR}\left(\mathrm{DMSO}-d_{6}\right): \delta=2.23(\mathrm{~s}, 3 \mathrm{H}$, $\left.\mathrm{CH}_{3}\right), 7.55-7.77$ (m, 5H, Ar-H), 10.20, 11.10 (br, 2H, 2NH, D $2 \mathrm{O}$-exchangeable); ${ }^{13} \mathrm{C}-\mathrm{NMR}$ $\left(\mathrm{DMSO}-d_{6}\right) \delta=21.1\left(1 \mathrm{C}, \mathrm{CH}_{3}\right), 121.1,128.4,129.2,131.8,138.1,142.6,143.7,152.2,162.5$ (11C, Ar-C), 163.5, 166.2, $182.7(3 \mathrm{C}, 3 \mathrm{C}=\mathrm{O}) ; \mathrm{MS}(70 \mathrm{eV}): \mathrm{m} / \mathrm{z}=326\left(\mathrm{M}^{+}, 100 \%\right)$; Anal. Calc. (Found) for $\mathrm{C}_{15} \mathrm{H}_{10} \mathrm{~N}_{4} \mathrm{O}_{3} \mathrm{~S}$ (326.33): C, 55.21 (55.15); H, 3.09 (3.17); N, 17.17 (17.26).

\subsection{Synthesis of \\ 6-Benzoyl-2-Mercapto-7-Methylthieno[2,3-d][1,2,4]Triazolo[1,5-a]Pyrimidin-8(3H)-One (9)}

$\mathrm{KOH}(0.56 \mathrm{~g}, 0.01 \mathrm{~mol})$ was dissolved through stirring in $20 \mathrm{~mL}$ of anhydrous methanol in a $250 \mathrm{~mL}$ flask. Carbon disulfide $(0.89 \mathrm{~g}, 0.01 \mathrm{~mol})$ was dissolved in anhydrous methanol $(5 \mathrm{~mL})$ and added dropwise to the stirring solution, followed by reflux. The solution of 2,3-diamino-benzoyl-methyl- thienopyrimidinone (3) (3 g, $0.01 \mathrm{~mol})$ in methanol (30 $\mathrm{mL})$ was added to the above reaction mixture and stirring under reflux $\left(75-80^{\circ} \mathrm{C}\right)$ for $8-10 \mathrm{~h}$. Initially, the solution was yellow, which then slowly turned to brown, and, as the reaction progressed, the evolution of hydrogen sulfide was observed. The reaction mixture was monitored via TLC (Ethyl-acetate: petroleum ether, 1:3). After completion of the reaction, the mixture was poured into a beaker containing ice water and acidified with $4 \mathrm{~N}, \mathrm{HCl}$ to maintain $\mathrm{pH} 4-5$. The final precipitate was separated, then filtered and recrystallized from the benzene in $70 \%$ yield as yellow crystals, m. p. $>350{ }^{\circ} \mathrm{C}$. IR $(\mathrm{KBr}): v_{\max }=3345(\mathrm{NH})$, 3040 (CH, aryl), 2937 (CH, alkyl), $2372(\mathrm{SH}), 1718,1678(2 \mathrm{C}=\mathrm{O}), 1627(\mathrm{C}=\mathrm{N}), 1584(\mathrm{C}=\mathrm{C})$ $\mathrm{cm}^{-1} ;{ }^{1} \mathrm{H}-\mathrm{NMR}\left(\mathrm{DMSO}-d_{6}\right): \delta=2.17\left(\mathrm{~s}, 3 \mathrm{H}, \mathrm{CH}_{3}\right), 2.62(\mathrm{~s}, 1 \mathrm{H}, \mathrm{SH}), 7.61-7.88(\mathrm{~m}, 5 \mathrm{H}, \mathrm{Ar}-\mathrm{H})$, 9.05 (br, $1 \mathrm{H}, \mathrm{NH}, \mathrm{D}_{2} \mathrm{O}$-exchangeable); ${ }^{13} \mathrm{C}-\mathrm{NMR}\left(\mathrm{DMSO}-d_{6}\right) \delta=19.8\left(1 \mathrm{C}, \mathrm{CH}_{3}\right), 120.7,128.7$, $129.5,132.1,138.6,142.3,143.5,148.9,151.8,161.7$ (12C, Ar-C), 164.5, 181.4 (2C, 2C=O); MS (70 eV): $\mathrm{m} / \mathrm{z}=342\left(\mathrm{M}^{+}, 93 \%\right)$; Anal. Calc. (Found) for $\mathrm{C}_{15} \mathrm{H}_{10} \mathrm{~N}_{4} \mathrm{O}_{2} \mathrm{~S}_{2}$ (342.39): C, 52.62 (52.55); H, 2.94 (2.86); N, 16.36 (16.45).

\subsection{Synthesis of}

6-Benzoyl-2-(Chloromethyl)-7-Methylthieno[2,3-d][1,2,4]Triazolo[1,5-a]Pyrimidin-8(3H)-One (10)

Chloroacetic acid $(0.95 \mathrm{~g}, 0.01 \mathrm{~mol})$ was dissolved in $35 \mathrm{~mL}$ of $4 \mathrm{~N}, \mathrm{HCl}$ and stirred into the mixture for nearly $30 \mathrm{~min}$. 2,3-diamino-benzoyl-methylthienopyrimidinone (3) ( $3 \mathrm{~g}$, $0.01 \mathrm{~mol}$ ) was added to the above solution with constant stirring; we continued stirring with reflux $\left(100{ }^{\circ} \mathrm{C}\right)$ for nearly $7-9 \mathrm{~h}$. The solid product was established by TLC (Ethyl acetate: petroleum ether, 1:1). The above hot solution was poured into ice cold water with stirring, followed by dropwise addition of con $\mathrm{NH}_{3}$; then the yellowish precipitate was filtered. The precipitate was then recrystallized from the dioxane in $79 \%$ yield as yellowish crystals, m. p. $>350{ }^{\circ} \mathrm{C}$. IR $(\mathrm{KBr}): v_{\max }=3341(\mathrm{NH}), 3035(\mathrm{CH}$, aryl $), 2933(\mathrm{CH}$, alkyl), 1724, $1680(2 \mathrm{C}=\mathrm{O}), 1625(\mathrm{C}=\mathrm{N}), 1581(\mathrm{C}=\mathrm{C}) \mathrm{cm}^{-1},{ }^{1} \mathrm{H}-\mathrm{NMR}\left(\mathrm{DMSO}-d_{6}\right): \delta=2.23(\mathrm{~s}, 3 \mathrm{H}$, $\left.\mathrm{CH}_{3}\right), 4.45$ (s, 2H, CH$\left.)_{2}\right), 7.60-7.86(\mathrm{~m}, 5 \mathrm{H}, \mathrm{Ar}-\mathrm{H}), 9.15$ (br, 1H, NH, D2O-exchangeable); ${ }^{13} \mathrm{C}-\mathrm{NMR}\left(\mathrm{DMSO}-d_{6}\right) \delta=20.5\left(1 \mathrm{C}, \mathrm{CH}_{3}\right), 50.2\left(1 \mathrm{C}, \mathrm{CH}_{2}\right), 120.4,128.4,129.2,132.3,138.1$, 142.5, 143.7, 152.2, 155.9, 162.5 (12C, Ar-C), 165.3, 181.8 (2C, 2C=O); MS (70 eV): m/z = 358 $\left(\mathrm{M}^{+}, 91 \%\right) ;$ Anal. Calc. (Found) for $\mathrm{C}_{16} \mathrm{H}_{11} \mathrm{ClN}_{4} \mathrm{O}_{2} \mathrm{~S}$ (358.80): C, 53.56 (53.50); H, 3.09 (3.15); $\mathrm{N}, 15.62$ (15.71). 
3.13. Synthesis of

6-Benzoyl-2-(((6-Benzoyl-7-Methyl-8-oxo-3,8-Dihydrothieno[2,3-d][1,2,4]Triazolo[1,5-a]Pyrimidin2-yl)Methyl)thio)-7-Methylthieno[2,3-d][1,2,4]Triazolo[1,5-a]Pyrimidin-8(3H)-One (11)

The $0.22 \mathrm{~g}, 0.01 \mathrm{~mol}$, of sodium metal was added to a solution of 2-mercapto-methylthieno-1,2,4-triazolopyrimidine (9) (3.42 g, $0.01 \mathrm{~mol})$ in $40 \mathrm{~mL}$ anhydrous methanol and stirred vigorously for $35 \mathrm{~min}$. The 2-chloromethyl-methylthieno- 1,2,4-triazolopyrimidine $(\mathbf{1 0})(3.58 \mathrm{~g}, 0.01 \mathrm{~mol})$ was added to the above reaction mixture in portions and continually stirred for $\left(90-100{ }^{\circ} \mathrm{C}\right)$ nearly $5-8 \mathrm{~h}$. A yellow compound so obtained was filtered, washed with the methanol and dried. The product was established via TLC (Ethyl acetate: petroleum ether, 1:1). The solid precipitate was then filtered and recrystallized from the DMF in $68 \%$ yield as yellow crystals, m. p. $>350^{\circ} \mathrm{C}$. IR $(\mathrm{KBr}): v_{\max }=3355(2 \mathrm{NH})$, $3050(\mathrm{CH}$, aryl $), 2940(\mathrm{CH}$, alkyl $), 1730,1728,1683,1675(4 \mathrm{C}=\mathrm{O}), 1628(\mathrm{C}=\mathrm{N}), 1585(\mathrm{C}=\mathrm{C})$ $\mathrm{cm}^{-1} ;{ }^{1} \mathrm{H}-\mathrm{NMR}$ (DMSO- $\left.d_{6}\right): \delta=2.16,2.28\left(\mathrm{~s}, 6 \mathrm{H}, 2 \mathrm{CH}_{3}\right), 4.05\left(\mathrm{~s}, 2 \mathrm{H}, \mathrm{CH}_{2}\right), 7.35-7.95(\mathrm{~m}$, $10 \mathrm{H}, \mathrm{Ar}-\mathrm{H}$ ), 9.80, 10.10 (br, 2H, 2NH, $\mathrm{D}_{2} \mathrm{O}$-exchangeable); ${ }^{13} \mathrm{C}-\mathrm{NMR}$ (DMSO- $d_{6}$ ) $\delta=20.3$, $20.8\left(2 \mathrm{C}, 2 \mathrm{CH}_{3}\right), 33.7\left(1 \mathrm{C}, \mathrm{CH}_{2}\right), 120.6,120.9,128.2,128.5,129.4,129.8,132.5,132.7,138.3$, 138.6, 142.1, 142.5, 143.2, 143.6, 144.3, 152.4, 152.8, 156.1, 163.1, 163.4 (24C, Ar-C), 166.1, 166.5, 182.2, 182.8 (4C, 4C=O); MS (70 eV): $\mathrm{m} / \mathrm{z}=664\left(\mathrm{M}^{+}, 90 \%\right)$; Anal. Calc. (Found) for $\mathrm{C}_{31} \mathrm{H}_{20} \mathrm{~N}_{8} \mathrm{O}_{4} \mathrm{~S}_{3}$ (664.73): C, 56.01 (56.12); $\mathrm{H}, 3.03$ (3.10); $\mathrm{N}, 16.86$ (16.73).

3.14. Synthesis of 6-Benzoyl-2-(Mercaptomethyl)-7-Methylthieno[2,3-d][1,2,4]Triazolo[1,5a]Pyrimidin-8(1H)-One (12)

A mixture of 2,3-diamino-benzoyl-methylthienopyrimidinone (3) (3 g, $0.01 \mathrm{~mol})$ and thioglycolic acid $(0.92 \mathrm{~g}, 0.01 \mathrm{~mol})$ in absolute ethanol $(25 \mathrm{~mL})$. The reaction solution was heated under reflux for $8-10 \mathrm{~h}$ by under control (TLC), then left to cool to room temperature. The separated crystalline product was filtered, washed with ethanol and crystallized from methanol in $73 \%$ yield as yellow crystals, m. p. $>350^{\circ} \mathrm{C}$. IR $(\mathrm{KBr}): v_{\max }=3370(\mathrm{NH}), 3040$ $(\mathrm{CH}$, aryl $), 2950\left(\mathrm{CH}\right.$, alkyl), $2355(\mathrm{SH}), 1730,1675(2 \mathrm{C}=\mathrm{O}), 1629(\mathrm{C}=\mathrm{N}), 1580(\mathrm{C}=\mathrm{C}) \mathrm{cm}^{-1}$; ${ }^{1} \mathrm{H}-\mathrm{NMR}\left(\mathrm{DMSO}-d_{6}\right): \delta=2.25\left(\mathrm{~s}, 3 \mathrm{H}, \mathrm{CH}_{3}\right), 2.60(\mathrm{~s}, 1 \mathrm{H}, \mathrm{SH}), 4.25\left(\mathrm{~s}, 2 \mathrm{H}, \mathrm{CH}_{2}\right), 7.55-7.82$ $(\mathrm{m}, 5 \mathrm{H}, \mathrm{Ar}-\mathrm{H}), 10.10$ (br, $1 \mathrm{H}, \mathrm{NH}, \mathrm{D}_{2} \mathrm{O}-$ exchangeable); ${ }^{13} \mathrm{C}-\mathrm{NMR}$ (DMSO- $\left.d_{6}\right) \delta=20.3(1 \mathrm{C}$, $\left.\mathrm{CH}_{3}\right), 30.1\left(1 \mathrm{C}, \mathrm{CH}_{2}\right), 120.1,128.6,129.5,131.8,137.6,142.4,143.5,157.1,158.8,160.2$ (12C, Ar-C), 166.4, 181.2 (2C, 2C=O); MS (70 eV): m/z = $356\left(\mathrm{M}^{+}, 100 \%\right)$; Anal. Calc. (Found) for $\mathrm{C}_{16} \mathrm{H}_{12} \mathrm{~N}_{4} \mathrm{O}_{2} \mathrm{~S}_{2}$ (356.42): C, 53.92 (53.84); $\mathrm{H}, 3.39$ (3.44); N, 15.72 (15.78).

\subsection{Synthesis of 2-Benzoyl-3-Methylthieno[ $\left.2^{\prime \prime}, 3^{\prime \prime}: 4^{\prime}, 5^{\prime}\right]$ Pyrimido[ $\left[1^{\prime}, 2^{\prime}: 2,3\right][1,2,4]$ Triazolo} [5,1-c][1,4] Thiazine-4,7(8H,10H)-Dione (13)

A well-stirred and ice-cooled suspension of finely powdered potassium hydroxide $(0.56 \mathrm{~g}, 0.01 \mathrm{~mol})$ and thienotriazolopyrimidinone (12) (3.56 g, $0.01 \mathrm{~mol})$ in dry dimethylformamide $(30 \mathrm{~mL})$. After complete addition, heating and stirring was continued at room temperature for $2-4 \mathrm{~h}$. The reaction mixture was cooled to $0{ }^{\circ} \mathrm{C}$, treated with the appropriate halogenated compound as ethylbromoacetate $(1.10 \mathrm{~mL}, 0.01 \mathrm{~mol})$, heated and stirred at room temperature for 18-22 $\mathrm{h}$ under control (TLC), then poured onto ice water. The resulting product was filtered off, dried and recrystallized from dimethylformamide in $80 \%$ yield as yellowish crystals, m. p. $>350{ }^{\circ} \mathrm{C}$. IR $(\mathrm{KBr}): v_{\max }=3050(\mathrm{CH}$, aryl), 2955 $\left(\mathrm{CH}\right.$, alkyl), 1733, 1682, $1677(3 \mathrm{C}=\mathrm{O}), 1631(\mathrm{C}=\mathrm{N}), 1582(\mathrm{C}=\mathrm{C}) \mathrm{cm}^{-1},{ }^{1} \mathrm{H}-\mathrm{NMR}$ (DMSO- $\left.d_{6}\right)$ : $\delta=2.28\left(\mathrm{~s}, 3 \mathrm{H}, \mathrm{CH}_{3}\right), 3.25\left(\mathrm{~s}, 2 \mathrm{H}, \mathrm{CH}_{2}\right.$, thiazine $), 3.70\left(\mathrm{~s}, 2 \mathrm{H}, \mathrm{CH}_{2}\right.$, thiazine $), 7.60-7.88(\mathrm{~m}$, $5 \mathrm{H}, \mathrm{Ar}-\mathrm{H}) ;{ }^{13} \mathrm{C}-\mathrm{NMR}$ (DMSO- $\left.d_{6}\right) \delta=20.5\left(1 \mathrm{C}, \mathrm{CH}_{3}\right), 33.2,37.5\left(2 \mathrm{C}, 2 \mathrm{CH}_{2}\right), 120.4,128.7$, 129.6, 131.9, 137.8, 142.7, 143.6, 158.5, 159.6, $161.3(12 \mathrm{C}, \mathrm{Ar}-\mathrm{C}), 165.9,167.2,182.1$ (3C, 3C=O); MS (70 eV): $\mathrm{m} / \mathrm{z}=396\left(\mathrm{M}^{+}, 95 \%\right)$; Anal. Calc. (Found) for $\mathrm{C}_{18} \mathrm{H}_{12} \mathrm{~N}_{4} \mathrm{O}_{3} \mathrm{~S}_{2}$ (396.44): $\mathrm{C}, 54.53$ (54.62); H, 3.05 (3.13); N, 14.13 (14.05).

3.16. Synthesis of 6-Benzoyl-7-Methyl-8-oxo-3,8-Dihydrothieno[2,3-d][1,2,4]Triazolo[1,5a]Pyrimidine-2-Carbox-ylic Acid (14)

Method A: A mixture of 2,3-diamino-benzoyl-methylthienopyrimidinone (3) (3 g, $0.01 \mathrm{~mol})$, oxalic acid $(0.9 \mathrm{~g}, 0.01 \mathrm{~mol})$ and anhydrous potassium carbonate $(1.4 \mathrm{~g}, 0.01 \mathrm{~mol})$ 
in dry dimethyl- formamide $(40 \mathrm{~mL})$; the mixture was refluxed for $20-25 \mathrm{~h}$ under control (TLC). The final product was filtered off, washed with cold water, dried and crystallized from the proper solvent. Method B: A mixture of 2,3-diamino-benzoyl- methylthienopyrimidinone (3) (3 g, $0.01 \mathrm{~mol})$ and oxalic acid $(0.9 \mathrm{~g}, 0.01 \mathrm{~mol})$ in a solution of phosphorus pentoxide and methanesulfonic acid (PPMA) at $110-125^{\circ} \mathrm{C}$ for $22-27 \mathrm{~h}$ under control (TLC). (PPMA was prepared by adding phosphorus pentoxide $(30 \mathrm{~g})$ to methane sulfonic acid $(210 \mathrm{~mL})$ in portions and stirring the mixture at $80{ }^{\circ} \mathrm{C}$ until the phosphorus pentoxide had completely dissolved.) Then, the mixture was allowed to cool at room temperature and then poured into the cool water. The solid product was obtained by being filtrated off, washed with ethanol and recrystallized from dioxane in $72 \%$ yield as yellow crystals, $\mathrm{m}$. p. $>350{ }^{\circ} \mathrm{C}$. IR $(\mathrm{KBr}): v_{\max }=3375(\mathrm{br}, \mathrm{OH}), 3360(\mathrm{NH}), 3058(\mathrm{CH}$, aryl $), 2960(\mathrm{CH}$, alkyl), $1745,1735,1679(3 \mathrm{C}=\mathrm{O}), 1630(\mathrm{C}=\mathrm{N}), 1585(\mathrm{C}=\mathrm{C}) \mathrm{cm}^{-1},{ }^{1} \mathrm{H}-\mathrm{NMR}\left(\mathrm{DMSO}-d_{6}\right): \delta=2.30(\mathrm{~s}$, $\left.3 \mathrm{H}, \mathrm{CH}_{3}\right), 7.63-7.90(\mathrm{~m}, 5 \mathrm{H}, \mathrm{Ar}-\mathrm{H}), 10.20$ (br, 1H, NH, D $2 \mathrm{O}$-exchangeable), 12.45 (br, 1H, $\mathrm{OH}, \mathrm{D}_{2} \mathrm{O}$-exchangeable); ${ }^{13} \mathrm{C}-\mathrm{NMR}\left(\mathrm{DMSO}_{6}\right) \delta=20.8\left(1 \mathrm{C}, \mathrm{CH}_{3}\right), 120.6,128.9,129.5,132.1$, 137.9, 142.4, 142.8, 143.8, 151.7, 160.9 (12C, Ar-C), 164.8, 169.1, 183.5 (3C, 3C=O); MS (70 eV): $m / z=354\left(\mathrm{M}^{+}, 90 \%\right)$; Anal. Calc. (Found) for $\mathrm{C}_{16} \mathrm{H}_{10} \mathrm{~N}_{4} \mathrm{O}_{4} \mathrm{~S}$ (354.34): C, 54.23 (54.31); $\mathrm{H}$, 2.84 (2.75); N, 15.81 (15.90).

3.17. Synthesis of 2-Benzoyl-8-Hydroxy-9-Mercapto-3-Methylpyrrolo[ $\left.1^{\prime}, 2^{\prime}: 2,3\right][1,2,4]$ Triazolo[1,5a]Thieno[2,3-d]Pyrimidine-4,7-Dione (15)

A solution of thienotriazolopyrimidinone (12) (3.56 g, $0.01 \mathrm{~mol})$, oxalic acid (0.9 g, $0.01 \mathrm{~mol})$ and anhydrous potassium carbonate $(1.4 \mathrm{~g}, 0.01 \mathrm{~mol})$ in dry dimethylformamide $(45 \mathrm{~mL})$. The reaction mixture was refluxed for 17-20 $\mathrm{h}$ under control (TLC). The formed precipitate was filtered off, washed with cold water, dried and crystallized from benzene in $70 \%$ yield as yellowish crystals, m. p. $>350{ }^{\circ} \mathrm{C}$. IR $(\mathrm{KBr}): v_{\max }=3380(\mathrm{br}, \mathrm{OH}), 3070(\mathrm{CH}$, aryl), 2955 (CH, alkyl), $2360(\mathrm{SH}), 1728,1680,1673(3 \mathrm{C}=\mathrm{O}), 1633(\mathrm{C}=\mathrm{N}), 1591(\mathrm{C}=\mathrm{C}) \mathrm{cm}^{-1}$; ${ }^{1} \mathrm{H}-\mathrm{NMR}\left(\mathrm{DMSO}-d_{6}\right): \delta=2.32\left(\mathrm{~s}, 3 \mathrm{H}, \mathrm{CH}_{3}\right), 2.70(\mathrm{~s}, 1 \mathrm{H}, \mathrm{SH}), 7.56-7.87(\mathrm{~m}, 5 \mathrm{H}, \mathrm{Ar}-\mathrm{H}), 12.10$ (br, $\left.1 \mathrm{H}, \mathrm{OH}, \mathrm{D}_{2} \mathrm{O}-\mathrm{exchangeable}\right) ;{ }^{13} \mathrm{C}-\mathrm{NMR}$ (DMSO-d 6$) \delta=21.1\left(1 \mathrm{C}, \mathrm{CH}_{3}\right), 98.5(1 \mathrm{C}, \mathrm{C}-\mathrm{SH}$, pyrrole), 120.4, 128.5, 129.4, 132.3, 138.6, 142.6, 143.5, 152.2, 159.7, 160.4 (12C, Ar-C), 178.7 (1C, C-OH, pyrrole) 165.1, 169.5, $183.9(3 \mathrm{C}, 3 \mathrm{C}=\mathrm{O})$; $\mathrm{MS}(70 \mathrm{eV}): \mathrm{m} / \mathrm{z}=410\left(\mathrm{M}^{+}, 98 \%\right)$; Anal. Calc. (Found) for $\mathrm{C}_{18} \mathrm{H}_{10} \mathrm{~N}_{4} \mathrm{O}_{4} \mathrm{~S}_{2}$ (410.42): C, 52.68 (52.75); H, 2.46 (2.40); N, 13.65 (13.71).

3.18. Synthesis of 2-Benzoyl-3-Methyl-8,13-

Dihydrothieno $\left[2^{\prime \prime \prime}, 3^{\prime \prime \prime}: 4^{\prime \prime}, 5^{\prime \prime}\right]$ Pyrimido $\left[1^{\prime \prime}, 2^{\prime \prime}: 2^{\prime}, 3^{\prime}\right][1,2,4]$ triazolo $\left[1^{\prime}, 5^{\prime}: 1,2\right]$ Pyrrolo[3,4b]Quinoxaline-4,7-Dione (16)

A mixture of compound 15 (4.10 g, $0.01 \mathrm{~mol})$ and anhydrous potassium carbonate (1.4 $\mathrm{g}, 0.01 \mathrm{~mol})$ in dry dimethylformamide $(40 \mathrm{~mL})$ was refluxed for $7-10 \mathrm{~h}$ under control (TLC). The product formed was filtered off, washed with methanol, dried and recrystallized from dioxane in $64 \%$ yield as yellow crystals, m. p. $>350^{\circ} \mathrm{C}$. IR $(\mathrm{KBr}): v_{\max }=3385-3370(2 \mathrm{NH})$, 3075 (CH, aryl), 2960 (CH, alkyl), 1735, 1685, 1675 (3C=O), 1635 (C=N), 1595 (C=C) cm ${ }^{-1}$; ${ }^{1} \mathrm{H}-\mathrm{NMR}\left(\mathrm{DMSO}-d_{6}\right): \delta=2.35\left(\mathrm{~s}, 3 \mathrm{H}, \mathrm{CH}_{3}\right), 7.01-7.92(\mathrm{~m}, 9 \mathrm{H}, \mathrm{Ar}-\mathrm{H}), 11.50,11.57(2 \mathrm{~s}, 2 \mathrm{H}$, 2NH, $\mathrm{D}_{2} \mathrm{O}-\mathrm{exchangeable);}{ }^{13} \mathrm{C}-\mathrm{NMR}\left(\mathrm{DMSO}-d_{6}\right) \delta=21.7\left(1 \mathrm{C}, \mathrm{CH}_{3}\right), 114.2,115.5,119.1$, $119.6,120.4,120.8,128.9,129.8,132.5,138.1,142.5,143.2,152.8,160.1,162.4$ (20 C, Ar-C), 166.7, 170.1, $183.5(3 \mathrm{C}, 3 \mathrm{C}=\mathrm{O})$; $\mathrm{MS}(70 \mathrm{eV}): \mathrm{m} / \mathrm{z}=466\left(\mathrm{M}^{+}, 100 \%\right)$; Anal. Calc. (Found) for $\mathrm{C}_{24} \mathrm{H}_{14} \mathrm{~N}_{6} \mathrm{O}_{3} \mathrm{~S}$ (466.48): C, 61.80 (61.73); $\mathrm{H}, 3.03$ (3.10); N, 18.02 (18.08).

\subsection{Synthesis of 2-Benzoyl-3-}

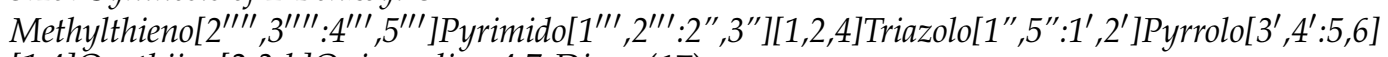
[1,4]Oxathiino[2,3-b]Quinoxaline-4,7-Dione (17)

A mixture of compound $15(4.10 \mathrm{~g}, 0.01 \mathrm{~mol})$ and 2,3- dichloroquinoxaline (1.99 $\mathrm{g}$, $0.01 \mathrm{~mol})$ in absolute ethanol $(40 \mathrm{~mL})$ containing $0.3 \mathrm{~mL}$ of TEA as a catalyst was refluxed for 24-28 h under control (TLC). The reaction solution was cooled, and the deposited solid was filtered off, dried and recrystallized from DMF in $66 \%$ yield as yellow crystals, $\mathrm{m}$. p. $>350{ }^{\circ} \mathrm{C}$. IR $(\mathrm{KBr}): v_{\max }=3080(\mathrm{CH}$, aryl $), 2960(\mathrm{CH}$, alkyl), 1730, 1680, $1675(3 \mathrm{C}=\mathrm{O})$, 
$1635(\mathrm{C}=\mathrm{N}), 1595(\mathrm{C}=\mathrm{C}) \mathrm{cm}^{-1} ;{ }^{1} \mathrm{H}-\mathrm{NMR}\left(\mathrm{DMSO}-d_{6}\right): \delta=2.37\left(\mathrm{~s}, 3 \mathrm{H}, \mathrm{CH}_{3}\right), 7.25-7.92(\mathrm{~m}$, 9H, Ar-H); ${ }^{13} \mathrm{C}-\mathrm{NMR}\left(\mathrm{DMSO}-d_{6}\right) \delta=21.9\left(1 \mathrm{C}, \mathrm{CH}_{3}\right), 119.5,120.8,127.1,127.4,128.5,129.2$, 129.8, 130.6, 132.4, 135.7, 137.9, 139.3, 140.5, 142.7, 143.5, 143.9, 149.6, 152.4, 160.8, 163.5 (22C, Ar-C), 166.5, 170.9, $183.8(3 \mathrm{C}, 3 \mathrm{C}=\mathrm{O}) ; \mathrm{MS}(70 \mathrm{eV}): \mathrm{m} / \mathrm{z}=536\left(\mathrm{M}^{+}, 94 \%\right) ;$ Anal. Calc. (Found) for $\mathrm{C}_{26} \mathrm{H}_{12} \mathrm{~N}_{6} \mathrm{O}_{4} \mathrm{~S}_{2}$ (536.54): C, 58.20 (58.28); H, 2.25 (2.16); N, 15.66 (15.74).

\subsection{Synthesis of}

8-Benzoyl-9-Methyl-[1,4]Oxathiino[3",2": $\left.3^{\prime}, 4^{\prime}\right]$ Pyrrolo[1' $\left.2^{\prime}: 2,3\right][1,2,4]$ Triazolo[1,5a]Thieno[2,3-d]Pyrimidine-3,10,13(2H)-Trione (18)

Method A: A mix of compound 15 (4.10 g, $0.01 \mathrm{~mol})$ and chloro-acetyl-chloride (1.13 g, $0.01 \mathrm{~mol})$ was stirred under reflux in dimethylformamide $(45 \mathrm{~mL})$ in the presence of anhydrous potassium carbonate $(0.015 \mathrm{~mol})$ for $22-26 \mathrm{~h}$ under control (TLC). The reaction solution was allowed to cool to room temperature, poured into cooled water (100 $\mathrm{mL})$ and neutralized. The final solid formed was filtered off, dried and crystallized from the appropriate solvent. Method B: To the stirring solution of compound 15 ( $4.10 \mathrm{~g}, 0.01 \mathrm{~mol})$ and chloro-acetyl-chloride $(1.13 \mathrm{~g}, 0.01 \mathrm{~mol})$ in glacial acetic acid $(40 \mathrm{~mL})$, activated zinc dust $(1.3 \mathrm{~g}, 0.02 \mathrm{~mol})$ was added portion-wise at room temperature over a period of one hour. Stirring was continued for an additional 4-6 h. The reaction solution was heated on a water bath $\left(90-95^{\circ} \mathrm{C}\right)$ for $12-17 \mathrm{~h}$ under control (TLC). After allowing the reaction mixture to cool to room temperature, it was poured into cold water $(100 \mathrm{~mL})$. The solid precipitate was filtered, washed with water, dried and crystallized from DMF in 68\% yield as yellowish crystals, m. p. $>350{ }^{\circ} \mathrm{C}$. IR $(\mathrm{KBr}): v_{\max }=3077(\mathrm{CH}$, aryl $), 2958(\mathrm{CH}$, alkyl), 1737, 1727, 1679, $1672(4 \mathrm{C}=\mathrm{O}), 1631(\mathrm{C}=\mathrm{N}), 1593(\mathrm{C}=\mathrm{C}) \mathrm{cm}^{-1} ;{ }^{1} \mathrm{H}-\mathrm{NMR}\left(\mathrm{DMSO}-d_{6}\right): \delta=2.34(\mathrm{~s}, 3 \mathrm{H}$, $\left.\mathrm{CH}_{3}\right), 5.10\left(\mathrm{~s}, 2 \mathrm{H}, \mathrm{CH}_{2}\right), 7.61-7.90(\mathrm{~m}, 5 \mathrm{H}, \mathrm{Ar}-\mathrm{H}) ;{ }^{13} \mathrm{C}-\mathrm{NMR}\left(\mathrm{DMSO}-d_{6}\right) \delta=21.3\left(1 \mathrm{C}, \mathrm{CH}_{3}\right)$, 80.6 (1C, $\mathrm{CH}_{2}$, oxathiine), 90.2 (1C, CH, oxathiine), 120.4, 128.6, 129.5, 132.1, 138.5, 142.4, 143.1, 152.3, 155.8, 161.2, 162.7 (13C, Ar-C), 165.9, 171.6, 183.2, 192.5 (4C, 4C=O); MS (70 eV): $\mathrm{m} / \mathrm{z}=450\left(\mathrm{M}^{+}, 90 \%\right) ;$ Anal. Calc. (Found) for $\mathrm{C}_{20} \mathrm{H}_{10} \mathrm{~N}_{4} \mathrm{O}_{5} \mathrm{~S}_{2}$ (450.44): $\mathrm{C}, 53.33$ (53.42); H, 2.24 (2.17); N, 12.44 (12.36).

3.21. Synthesis of 7-Benzoyl-2-Mercapto-8-Methyl-1HImidazo[4", $\left.5^{\prime \prime}: 3^{\prime}, 4^{\prime}\right]$ Pyrrolo[1',2':2,3][1,2,4]Triazolo[1,5-a]Thieno[2,3-d]Pyrimidine-9,12-Dione (19)

Method A: A mixture of compound 15 (4.10 g, $0.01 \mathrm{~mol})$ and thiourea $(0.76 \mathrm{~g}, 0.01 \mathrm{~mol})$ in $45 \mathrm{~mL}$ of DMF was refluxed for 14-18 h under control (TLC). The final product formed was filtered off, washed with methanol, dried and recrystallized from a suitable solvent. Method B: A mix of compound $15(4.10 \mathrm{~g}, 0.01 \mathrm{~mol})$ and thiourea $(0.76 \mathrm{~g}, 0.01 \mathrm{~mol})$ was stirred under reflux in dioxane $(45 \mathrm{~mL})$ in the existence of the catalytic amount of piperidine $(1 \mathrm{~mL})$ for 18-22 $\mathrm{h}$. The reaction solution was allowed to cooling at room temperature and poured into cooled water, and the final precipitate was filtered off, washed with methanol, dried and crystallized from DMF in $70 \%$ yield as brownish crystals, m. p. $>350{ }^{\circ} \mathrm{C}$. IR $(\mathrm{KBr})$ : $\nu_{\max }=3355(\mathrm{NH}), 3050(\mathrm{CH}, \operatorname{aryl}), 2945(\mathrm{CH}$, alkyl), 2357(SH), 1729, 1681, $1670(3 \mathrm{C}=\mathrm{O})$, $1626(\mathrm{C}=\mathrm{N}), 1586(\mathrm{C}=\mathrm{C}) \mathrm{cm}^{-1} ;{ }^{1} \mathrm{H}-\mathrm{NMR}\left(\mathrm{DMSO}-d_{6}\right): \delta=2.28\left(\mathrm{~s}, 3 \mathrm{H}, \mathrm{CH}_{3}\right), 7.55-7.82(\mathrm{~m}$, $5 \mathrm{H}, \mathrm{Ar}-\mathrm{H}), 10.83$ (s, 1H, SH), 11.90 (s, 1H, NH, D ${ }_{2} \mathrm{O}$-exchangeable); ${ }^{13} \mathrm{C}-\mathrm{NMR}$ (DMSO- $d_{6}$ ) $\delta=21.1\left(1 \mathrm{C}, \mathrm{CH}_{3}\right), 120.3,128.4,129.3,130.1,132.5,137.8,140.3,142.7,143.2,157.4,161.6$, 163.2 (14C, Ar-C), 164.7 (1C,1C=O), 168.9 (1C, C-SH, imidazole), 170.2, 183.4 (2C, 2C=O); MS (70 eV): $\mathrm{m} / \mathrm{z}=434\left(\mathrm{M}^{+}, 85 \%\right)$; Anal. Calc. (Found) for $\mathrm{C}_{19} \mathrm{H}_{10} \mathrm{~N}_{6} \mathrm{O}_{3} \mathrm{~S}_{2}$ (434.45): $\mathrm{C}, 52.53$ (52.62); H, 2.32 (2.40); N, 19.34 (19.27).

3.22. Synthesis of 10-Benzoyl-9-Methyl-3-Phenyl-1H-

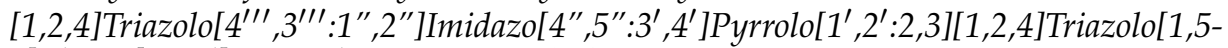
a]Thieno[2,3-d]Pyrimidine-5,8-Dione (20)

Method A: A mixture of compound 19 (4.34 g, $0.01 \mathrm{~mol})$ and benzohydrazide (1.36 $\mathrm{g}$, $0.01 \mathrm{~mol})$ and anhydrous potassium carbonate $(1.4 \mathrm{~g}, 0.01 \mathrm{~mol})$ in dry dimethylformamide $(40 \mathrm{~mL})$. The reaction solution was heated under reflux for 13-16 h under control (TLC), 
and then allowed to cool and poured into ice water. The formed solid product was collected by filtration and crystallized from the proper solvent. Method B: A solution of compound 19 (4.34 g, $0.01 \mathrm{~mol})$ and benzohydrazide $(1.36 \mathrm{~g}, 0.01 \mathrm{~mol})$ in ethanol $(40 \mathrm{~mL})$ containing sodium ethoxide [prepared by dissolving sodium metal $(0.23 \mathrm{~g}, 0.01 \mathrm{~mol})$ in ethanol] was heated under reflux for 11-15 h, the reaction mixture was cooled and the deposited precipitate was filtered off, washed with ice water/ethanol and acidified with $10 \% \mathrm{HCl}$. The formed precipitate was filtered, dried and crystallized from dioxane in $73 \%$ yield as yellowish crystals, m. p. $>350{ }^{\circ} \mathrm{C}$. IR (KBr): $v_{\max }=3372(\mathrm{NH}), 3058(\mathrm{CH}$, aryl), 2951 $\left(\mathrm{CH}\right.$, alkyl), 1733, 1684, $1676(3 \mathrm{C}=\mathrm{O}), 1631(\mathrm{C}=\mathrm{N}), 1579(\mathrm{C}=\mathrm{C}) \mathrm{cm}^{-1},{ }^{1} \mathrm{H}-\mathrm{NMR}\left(\mathrm{DMSO}-d_{6}\right)$ : $\delta=2.32\left(\mathrm{~s}, 3 \mathrm{H}, \mathrm{CH}_{3}\right), 7.15-7.98(\mathrm{~m}, 10 \mathrm{H}, \mathrm{Ar}-\mathrm{H}), 12.01$ (s, 1H, NH, D2O-exchangeable); ${ }^{13} \mathrm{C}-\mathrm{NMR}\left(\mathrm{DMSO}-d_{6}\right) \delta=21.6\left(1 \mathrm{C}, \mathrm{CH}_{3}\right), 119.2,120.7,127.8,128.2,129.4,129.8,130.5,131.8$, 132.9, 136.5, 138.7, 142.5, 143.7, 150.8, 151.2, 155.4, 160.9, 162.7 (22C, Ar-C), 165.1, 168.8, $183.4(3 \mathrm{C}, 3 \mathrm{C}=\mathrm{O})$; $\mathrm{MS}(70 \mathrm{eV}): \mathrm{m} / \mathrm{z}=518\left(\mathrm{M}^{+}, 100 \%\right)$; Anal. Calc. (Found) for $\mathrm{C}_{26} \mathrm{H}_{14} \mathrm{~N}_{8} \mathrm{O}_{3} \mathrm{~S}$ (518.51): C, 60.23 (60.33); H, 2.72 (2.65); N, 21.61 (21.68).

\subsection{Pharmacological Screening}

\subsubsection{Ethics Approval and Consent to Participate}

No humans or animals were used in this study, nevertheless: all the procedures are carried out under the Medical Research Ethics Committee of Mansoura University, Faculty of Pharmacy, Department of Pharmacognosy, 35516, Egypt.

\subsubsection{Human and Animal Rights}

No humans or animals were used in the study. The research was conducted according to ethical standards in vitro.

\subsubsection{Chemicals and Drugs}

Types of human carcinoma cancer cell line (CNE2, KB, MCF-7 and MGC-803) are derived from the National Cancer institute, Cairo University, Cairo, Egypt, and 5-Fluorouracil and DMSO were purchased from Sigma-Aldrich (Saint Louis, MO, USA).

\subsubsection{Materials and Methods (In Vitro Cytotoxicity)}

The in vitro cytotoxicity of the synthesized compounds against different cancer cell lines was performed with the MTT assay, according to the method found in $[34,38,40,48]$. The MTT assay is based on the reduction of the soluble 3-(4,5-dimethyl-2-thiazolyl)-2,5diphenyl-2H-tetrazoliumbromide (MTT) into a blue-purple formazan product, mainly by mitochondrial reductase activity inside living cells. The cells used in the cytotoxicity assay were cultured in the suitable cell culture medium (RPMI 1640) medium supplemented with $10 \%$ fetal calf serum. Cells suspended in the medium $\left(2 Y^{\prime} 104 / \mathrm{mL}\right)$ were plated in 96-well culture plates and incubated at $37^{\circ} \mathrm{C}$ in a $5 \% \mathrm{CO}_{2}$ incubator. After $12 \mathrm{~h}$, the test sample $(2 \mathrm{~mL})$ was added to the cells $\left(2 \mathrm{Y}^{\prime} 104\right)$ in 96 -well plates and cultured at $37^{\circ} \mathrm{C}$ for 3 days. The cultured cells were mixed with $20 \mathrm{~mL}$ of MTT solution and incubated for $4 \mathrm{~h}$ at $37^{\circ} \mathrm{C}$. The supernatant was carefully removed from each well, and $100 \mathrm{~mL}$ of DMSO was added to each well to dissolve the formazan crystals, which were formed by the cellular reduction of MTT. After mixing with a mechanical plate mixer, the absorbance of each well was measured by a microplate reader using a test wavelength of $570 \mathrm{~nm}$. The results were expressed as the $\mathrm{IC}_{50}$, which is the concentration of the drugs inducing a $50 \%$ inhibition of cell growth of treated cells, when compared to the growth of control cells. Each experiment was performed at least 3 times. There was a good reproducibility between replicate wells with standard errors below $10 \%$.

\section{Conclusions}

In the current work, we successfully prepared and developed 2,3-diamino-6-benzoyl5-methylthieno[2,3-d]pyrimidin-4(3H)-one (3) as starting material to synthesize various new heterocyclic, such as thieno[2,3-d][1,2,4]triazolo[1,5-a] pyrimidinone-thieno[2,3-d] 
[1,2,4]triazolo [1,5-a]pyrimidinones, thienopyrimidotriazolothiazine-diones, pyrrolotriazolothienopyrimidines, thienopyrimidotriazolopyrroloquinoxalindiones, thienopyrimidotriazolopyrrolo-oxathiinoquinoxalines, 1,4-oxathiinopyrrolo-triazolothienopyrimidintriones, imidazopyrrolotriazolothienopyrimidindiones and 1,2,4-triazoloimidazopyrrolotriazolothienopyrimidine-diones, which were prepared and described using different methods and high techniques that produced good yields. In addition, the anticancer properties of the new compounds were studied in vitro; we in screened all compounds for cytotoxic and antiproliferative effects against the types of human carcinoma cancer cell line (CNE2, KB, MCF-7 and MGC-803). The compounds 20, 19, 17, 16, 11 and 18 showed potent cytotoxic and anticancer efficacy, because these compounds contain many functional groups and many heterocyclic, such as the thienopyrimidine, 1,2,4-triazole, 1,4-thiazine, pyrrole, quinoxaline, 1,4-oxathiine and imidazole moieties, according to previous scientific studies. 1,2,4-triazolo-imidazopyrrolotriazolo-thienopyrimidin-dione (20) is a promising anticancer molecule with multiple modes of actions, such as antiproliferative and angiopreventive effects, together with its remarkable apoptosis-inducing action [48-50].

Author Contributions: A.A.A.-H., S.A.A.-H. and M.E.A.Z. participated in the synthesis, purification and characterization of the new compounds; the Department of Pharmacognosy, Faculty of Pharmacy, Mansoura University, Egypt, participated in the evaluation of the newly synthesized compounds for anticancer activities. S.A.A.-H. participated in the work of physical and chemical experiments and some of the measurements for the prepared compounds, with the interpretation of many results. M.E.A.Z. participated in the interpretation of spectroscopy of new compounds and the review of the manuscript. A.A.A.-H. participated in the interpretation of the results, writing, revision and correspondence to the journal of molecules until the manuscript was accepted. All authors have read and agreed to the published version of the manuscript.

Funding: This research received no external funding.

Institutional Review Board Statement: "Not applicable" this study not involving humans or animals.

Informed Consent Statement: "Not applicable" this study not involving humans.

Data Availability Statement: All data are contained within the article and the experimental section.

Acknowledgments: The authors are extremely grateful to prof. Farid A. Badria and the Department of Pharmacognosy, Faculty of Pharmacy, Mansoura University, 35516 Egypt, for helping us to screen the newly synthesized compounds for anticancer activity.

Conflicts of Interest: The authors declare no conflict of interest.

Sample Availability: Samples of the synthesized compounds are available from the authors.

\section{References}

1. Galluzzi, L.; Buque, A.; Kepp, O.; Zitvogel, L.; Kroemer, G. Immunological effects of conventional chemotherapy and targeted anticancer agents. Cancer Cell 2015, 28, 690-714. [CrossRef]

2. Monika, G.; Chander, M. Development of drugs based on imidazole and benzimidazole bioactive heterocycles: Recent advances and future directions. Med. Chem. Res. 2016, 25, 173-210.

3. Kukolja, S.; Draheim, S.E.; Graves, B.J.; Hunden, D.C.; Pfeil, J.L.; Cooper, R.D.G.; Ot, J.L.; Couter, F.T. Orally absorbable cephalosporin antibiotics. 2. Structure-activity studies of bicyclic glycine derivatives of 7-aminodeacetoxycephalosporanic acid. J. Med. Chem. 1985, 28, 1896-1903. [CrossRef]

4. Abu-Hashem, A.A.; Abu-Zied, K.M.; El-Shehry, M.F. Synthetic utility of bifunctional thiophene derivatives and antimicrobial evaluation of the newly synthesized agents. Mon. Chem. 2011, 142, 539-545. [CrossRef]

5. Abu-Hashem, A.A. Synthesis and biological activity of pyrimidines, quinolines, thiazines and pyrazoles bearing a common thieno moiety. Acta Pol. Pharm. Drug Res. 2018, 75, 59-70.

6. Sirakanyan, S.N.; Akopyan, E.K.; Paronikyan, R.G.; Akopyan, A.G.; Ovakimyan, A.A. Synthesis and anticonvulsant activity of 7(8)-amino derivatives of condensed thieno[3,2-d]pyrimidines. Pharm. Chem. J. 2016, 50, 296-300. [CrossRef]

7. Hafez, H.N.; Hussein, H.A.R.; El-Gazzar, A.B.A. Synthesis of substituted thieno[2,3-d]pyrimidine-2,4-dithiones and their Sglycoside analogues as potential antiviral and antibacterial agents. Eur. J. Med. Chem. 2010, 45, 4026-4034. [CrossRef]

8. Abu-Hashem, A.A.; El Shehry, M.F.; Badria, F.A. Design and synthesis of novel thiophenecarbohydrazide, thienopyrazole and thienopyrimidine derivatives as antioxidant and antitumor agents. Acta Pharm. 2010, 60, 311-323. [CrossRef] 
9. Alqasoumi, S.I.; Ragab, F.A.; Alafeefy, A.M.; Galal, M.; Ghorab, M.M. Radioprotective and antitumor activity of some novel amino acids and imidazoles containing thieno[2,3-d]pyrimidine moiety. Phosphorus Sulfur Silicon 2009, 184, 3241-3257. [CrossRef]

10. Ross, C.R.; Temburnikar, K.W.; Wilson, G.M.; Seley-Radtke, K.L. Mitotic arrest of breast cancer MDA-MB-231 cells by halogenated thieno[3,2-d]pyrimidines. Bioorg. Med. Chem. Lett. 2015, 25, 1715-1717. [CrossRef]

11. El-Gazzar, A.B.A.; Youssef, A.M.S.; Youssef, M.M.; Abu-Hashem, A.A.; Badria, F.A. Design and synthesis of azolopyrimidoquinolines, pyrimidoquinazolines as anti-oxidant, anti-inflammatory and analgesic activities. Eur. J. Med. Chem. 2009, 44, 609-624. [CrossRef]

12. Abu-Hashem, A.A.; Gouda, M.A.; Badria, F.A. Synthesis of some new pyrimido $\left[2^{\prime}, 1^{\prime}: 2,3\right]$ thiazolo $[4,5$-b] quinoxaline derivatives as anti-inflammatory and analgesic agents. Eur. J. Med. Chem. 2010, 45, 1976-1981. [CrossRef] [PubMed]

13. Prugh, J.D.; Hartman, G.D.; Mallorga, P.J.; McKeever, B.M.; Michelson, S.R.; Murcko, M.A.; Schwam, H.; Smith, R.L.; Sondey, J.M.; Springer, J.P.; et al. New isomeric classes of topically active ocular hypotensive carbonic anhydrase inhibitors: 5-substituted thieno [2,3-b] thiophene-2-sulfonamides and 5-substituted thieno [3,2-b] thiophene-2-sulfonamides. J. Med. Chem. 1991, 34, 1805-1818. [CrossRef] [PubMed]

14. Egbertson, M.S.; Cook, J.J.; Bednar, B.; Prugh, J.D.; Bednar, R.A.; Gaul, S.L.; Gould, R.J.; Hartman, G.D.; Homnick, C.F.; Holahan, M.A.; et al. Non-peptide GPIIb/IIIa inhibitors. 20. Centrally constrained-thienothiophene $\alpha$-sulfona- mides Are potent, long acting in vivo inhibitors of platelet aggregation. J. Med. Chem. 1999, 42, 2409-2421. [CrossRef] [PubMed]

15. Tamboli, R.S.; Amrutkar, R.D.; Jain, K.S.; Kathiravan, M.K. Synthesis and in vivo antihyperlipidemic potential of novel substituted thieno [3, 2-d] pyrimidines. Lett. Drug Des. Discov. 2013, 10, 906-915. [CrossRef]

16. Ashalatha, B.V.; Narayana, B.; Raj, K.V.; Kumari, N.S. Synthesis of some new bioactive 3-amino-2-mercapto-5,6,7,8-tetrahydro [1]benzothieno[2,3-d]pyrimidin-4(3H)-one derivatives. Eur. J. Med. Chem. 2007, 42, 719-728. [CrossRef] [PubMed]

17. Rashad, A.E.; Heikal, O.A.; El-Nezhawy, A.O.H.; Abdel-Megeid, F.M.E. Synthesis and isomerization of thienotriazolopyrimidine and thienotetrazolo pyrimidine derivatives with potential anti-inflammatory activity. Heteroat. Chem. 2005, 16, 226-234. [CrossRef]

18. Ashour, H.M.; Shaaban, O.G.; Rizk, O.H.; El-Ashmawy, I.M. Synthesis and biological evaluation of thieno[ $\left.2^{\prime}, 3^{\prime}: 4,5\right]$ pyrimido $[1,2-\mathrm{b}][1,2,4]$ triazines and thieno[2,3-d][1,2,4] triazolo[1,5-a]pyrimidines as anti- inflammatory and analgesic agents. Eur. J. Med. Chem. 2013, 62, 341-351. [CrossRef]

19. Abu-Hashem, A.A.; Hussein, H.A.R.; Abu-zied, K.M. Synthesis of novel 1,2,4-triazolopyrimidines and their evaluation as antimicrobial agents. Med. Chem. Res. 2016, 26, 120-130. [CrossRef]

20. Abu-Hashem, A.A.; Abu-Zied, K.M.; Zaki, M.E.A.; El-Shehry, M.F.; Awad, H.M.; Khedr, M.A. Design, synthesis, and anticancer potential of the enzyme (PARP-1) inhibitor with computational studies of new triazole, thiazolidinone, -thieno[2,3-d] pyrimidinones. Lett. Drug Des. Discov. 2020, 17, 799-819. [CrossRef]

21. Abu-Hashem, A.A.; Hussein, H.A.R. Synthesis and antitumor activity of new pyrimidine and caffeine derivatives. Lett. Drug Des. Discov. 2015, 12, 471-478. [CrossRef]

22. Nagamatsu, T.; Yamasaki, H.; Akiyama, T.; Hara, S.; Mori, K.; Kusakabe, H. Facile and general syntheses of 3- and/or 5-substituted 7- $\beta$-d-ribofuranosyl-7H-[1,2,4]triazolo[3,4-i]purines as a new class of potential xanthine oxidase inhibitors. Synthesis 1999, 1999, 655-663. [CrossRef]

23. Nagamatsu, T.; Yamasaki, H.; Fujita, T.; Endo, K.; Machida, H. Novel xanthine oxidase inhibitor studies. Part 2. Synthesis and xanthine oxidase inhibitory activities of 2-substituted 6-alkylidenehydrazino- or 6-arylmethylidenehydrazino-7H-purines and 3and/or 5-substituted 9H-1,2,4-triazolo[3,4-i]purines. J. Chem. Soc. Perkin Trans. 1999, 1, 3117-3125. [CrossRef]

24. Nagamatsu, T.; Ahmed, S.; Hossion, A.M.L.; Ohno, S. Synthesis of thieno[3,2-e] [1,2,4]triazolo[1,5-c] pyrimidin-5(6H)-ones via their $[1,2,4]$ triazolo[4,3-c]pyrimidine compounds as new ring systems by dimroth-type rearrangement. Heterocycles 2007, 73 , 777-793. [CrossRef]

25. Pectasides, D.; Yianniotis, H.; Alevizakos, N.; Bafaloukos, D.; Barbounis, V.; Varthalitis, J.; Dimitriadis, M.; Athanassiou, A. Treatment of metastatic malignant melanoma with dacarbazine, vindesine and cisplatin. Br. J. Cancer 1989, 60, 627-629. [CrossRef] [PubMed]

26. DeSimone, R.W.; Currie, K.S.; Mitchell, S.A.; Darrow, J.W.; Pippin, D.A. Privileged structures: Applications in drug discovery. Comb. Chem. High Throughput Screen. 2004, 7, 473-494. [CrossRef]

27. Ortiz, J.A. Sertaconazole (FI-7045). A new antifungal agent. Arzneim. Forsch. 1992, 42, 689-690.

28. Shin, J.M.; Munson, K.; Vagin, O.; Sachs, G. The gastric H?-KATPase: Structure, function, and inhibition. Pflug. Arch. Eur. J. Phy. 2008, 457, 609-622. [CrossRef]

29. Fellenius, E.; Berglindh, T.; Sachs, G.; Olbe, L.; Elander, B.; Sjostrand, S.; Wallmark, B. Substituted benzimidazoles inhibit gastric acid secretion by blocking (H++ K+) ATPase. Nature 1981, 290, 159-161. [CrossRef]

30. Corcostegui, R.; Labeaga, L.; Innerarity, A.; Berisa, A.; Orjales, A. Preclinical pharmacology of bilastine, a new selective histamine $\mathrm{H} 1$ receptor antagonist: Receptor selectivity and in vitro antihistaminic activity. Drugs RD 2005, 6, 371-384. [CrossRef]

31. Burnier, M.; Brunner, H.R. Angiotensin II receptor antagonists. Lancet 2000, 355, 637-645. [CrossRef]

32. Kapoor, V.K.; Chadha, R.; Venisetty, P.K.; Prasanth, S. Medicinal significance of nitroimidazoles: Some recent advances. J. Sci. Ind. Res. 2003, 62, 659-665.

33. Biron, K.K.; Harvey, R.J.; Chamberlain, S.C.; Good, S.S.; Smith, A.A., III; Davis, M.G.; Talarico, C.L.; Miller, W.H.; Ferris, R.; Dornsife, R.E.; et al. Potent and selective inhibition of human cytomegalovirus replication by 1263W94: A benzimidazole L-riboside with a unique mode of action. Antimicrob. Agents Chemother. 2002, 46, 2365-2372. [CrossRef] 
34. Abu-Hashem, A.A.; Youssef, M.M.; Hussein, H.A.R. Synthesis, antioxidant, antitumor activities of some new thiazolo pyrimidines, pyrrolothiazolopyrimidines and triazolopyrrolothiazolo pyrimidines derivatives. J. Chin. Chem. Soc. 2011, 58, 41-48. [CrossRef]

35. Abu-Hashem, A.A.; Youssef, M.M. Synthesis of new visnagen and khellin furochromone pyrimidine derivatives and their anti-inflammatory and analgesic activity. Molecules 2011, 16, 1956-1972. [CrossRef]

36. Abu-Hashem, A.A. Synthesis and reaction of novel spiro-pyrimidine derivatives. J. Heterocycl. Chem. 2014, 51, 1020-1026. [CrossRef]

37. Abu-Hashem, A.A.; Badria, F.A. Design, synthesis of novel thiourea and pyrimidine derivatives as potential antitumor agents. J. Chin. Chem. Soc. 2015, 62, 506-512. [CrossRef]

38. Abu-Hashem, A.A.; El-Shazly, M. Synthesis of new quinoxaline, pyrimidine, and pyrazole furochromone derivatives as cytotoxic agents. Mon. Chem. 2017, 148, 1853-1863. [CrossRef]

39. Abu-Hashem, A.A.; El-Shazly, M. Synthesis of new isoxazole-, pyridazine-, pyrimidopyrazines and their anti-inflammatory and analgesic activity. Med. Chem. 2018, 14, 356-371. [CrossRef] [PubMed]

40. Abu-Hashem, A.A.; Gouda, M.A.; Badria, F.A. Design, synthesis and identification of novel substituted isothiochromene analogs as potential antiviral and cytotoxic agents. Med. Chem. Res. 2018, 27, 2297-2311. [CrossRef]

41. Abu-Hashem, A.A. Synthesis of new furothiazolo pyrimido quinazolinones from visnagenone or khellinone and antimicrobial activity. Molecules 2018, 23, 2793. [CrossRef]

42. Abu-Hashem, A.A.; Zaki, M.E.A. Direct amination and synthesis of fused N-substituted isothiochromene derivatives. J. Heterocycl. Chem. 2019, 56, 886-894. [CrossRef]

43. Abu-Hashem, A.A.; El-Shazly, M. Synthesis and antimicrobial evaluation of novel triazole, tetrazole, and spiropyrimidinethiadiazole derivatives. Polycycl Aromat Compd. 2019. [CrossRef]

44. Abu-Hashem, A.A.; Al-Hussain, S.A.; Zaki, M.E.A. Synthesis of novel benzodifuranyl; 1, 3, 5-triazines; 1, 3, 5-oxadiazepines; and thiazolopyrimidines derived from visnaginone and khellinone as anti- inflammatory and analgesic agents. Molecules 2020, 25, 220. [CrossRef] [PubMed]

45. Abu-Hashem, A.A.; Hussein, H.A.R.; Aly, A.S. Synthesis and antimicrobial activity of novel 1,2,4-triazolopyrimidofuro- quinazolinones from natural furochromones (visnagenone and khellinone). Med. Chem. 2020, 16. [CrossRef]

46. Abu-Hashem, A.A.; Fathy, U.; Gouda, M.A. Synthesis of 1,2,4-triazolopyridazines, isoxazolofuropyrida-zines, and tetrazolopyridazines as antimicrobial agents. J. Heterocycl. Chem. 2020, 57, 3461-3474.

47. Abu-Hashem, A.A. Synthesis and antimicrobial activity of new 1,2,4-triazole, 1,3,4-oxadiazole, 1,3,4-thiadiazole, thiopyrane, thiazolidinone and azepine derivatives. J. Heterocycl. Chem. 2021, 58, 74-92. [CrossRef]

48. Abu-Hashem, A.A. Synthesis of new pyrazoles, oxadiazoles, triazoles, pyrrolotriazines and pyrrolotriazepines as potential cytotoxic agents. J. Heterocycl. Chem. 2021, 58, 805-821. [CrossRef]

49. Sunkari, S.; Bonam, S.R.; Subba Rao, A.V.; Riyaz, S.; Nayak, V.L.; Kumar, H.M.S.; Kamal, A.; Babu, B.N. Synthesis and biological evaluation of new bisindole-imidazopyridine hybrids as apoptosis inducers. Bioorg. Chem. 2019, 87, 484-494. [CrossRef] [PubMed]

50. Sultana, F.; Manasa, K.L.; Shaik, S.P.; Bonam, S.R.; Kamal, A. Zinc dependent histone deacetylase inhibitors in cancer therapeutics: Recent update. Curr. Med. Chem. 2019, 26, 7212-7280. [CrossRef] 